\title{
Life Cycle Portfolio Choice: A Swiss Perspective
}

\author{
Florian Zainhofer ${ }^{*}$
}

JEL classification: G11, D14, D91, H55

Keywords: Personal finance, financial planning, life cycle model, portfolio choice.

\section{Introduction}

In Switzerland, proposals have been made to individualize the funded occupational retirement provision scheme $(B V G)$. These would imply a transfer of the investment responsibilities and risks inherent in this scheme to the individual's sphere. However, most individuals are not equipped with investment know-how. As a consequence, some financial economists have expressed concerns: Bodie (2003) e.g. fears that individuals' welfare could decline because risk would be transferred "to those who may be least qualified to manage it." Policy makers are facing a similar dilemma: they are uncertain to what extent and how exactly the savings and investment process should be individualized in order to be welfare-enhancing.

Thus, knowledge about individually optimal life cycle investment strategies and their determinants is a real concern to different parties: to households who are increasingly forced to save and invest for retirement on their own and who

* This project was completed while the author was visiting CEMFI in Madrid under Swiss National Science Foundation research grant no. PBFR1-115552. I wish to thank two anonymous referees, my thesis advisor Martin Wallmeier and Johannes Binswanger for their constructive advice and guidance. I am also grateful to seminar participants at Fribourg University for valuable comments and suggestions, Pawel Bednarek for granting me access to and providing help with Fribourg University's high performance computing cluster, Lorenz Küng for helpful comments on an earlier draft of the empiric part, Michel Kolly and Sandra Siegenthaler from the Swiss Federal Office of Statistics (FOS) for help with the SLFS data and Elisabeth Aebischer (also FOS) for providing the mortality data. All errors are my own. Contact during 2007: zainhofer@cemfi.es, tel: +34 620 885534. Author afilliation: Chair for Financial Management, Fribourg University, Bd de Perolles 90, CH-1700 Fribourg, Email: florian.zainhofer@unifr.ch.

1 Bodie (2003), p. 28. 
thus bear higher investment risks; to policy makers who wish to improve public retirement provision and also to asset managers seeking ways to efficiently craft new provision products for second and third pillar saving.

To deal with this concern, theory would actually be available: early models of long horizon portfolio choice have recently been refined by specifically accounting for realistic labor income streams, the explicit life-cycle nature peculiar to real-life savings- and investment decisions and various financial and real assets, as well as alternative preference structures. ${ }^{2}$

However, because some of the early models contradict existing empirical findings on households' investments and have thus given rise to portfolio puzzles, ${ }^{3}$ most of the literature is now anxious to resolve these puzzles by replicating empirical findings with new models: a positive tradition has effectively developed. This seems natural because one could think that real-life investors cannot generally be 'wrong'. In line with this notion, the fact that young investors do not invest all of their wealth in stocks, as predicted by early life-cycle models, is often cited to reject these models.

Contrary to this view, we believe that many investors are indeed 'wrong' and would behave differently if they knew better: e.g., it is not absurd to invest $100 \%$ of what little wealth young liquidity constrained investors have, in stocks. In fact, it is quite rational to do so once you consider that most of their wealth consists of relatively save future labor income. Thus, our perspective is normative: we have in mind a consultant who is frequented for investment advice and who explores clients' personal situations, means and investment goals before framing an optimal strategy. In this notion, we want to contribute to a normative decision framework for life-cycle portfolio choice to help financially illiterate investors make informed decisions. We do this by analysing how life-cycle portfolio choice depends on the exact shape of an investor's age-earnings profile and its stochastic properties. Specifically, we use panel data from the Swiss Labor Force Survey $(S L F S)$ to conduct an empirical analysis identifying representative age-

2 See e.g. Campbell et al. (2000), Campbell and Viceira (2002), Cocco (2004), Cocco et al. (2005), Davis et al (2004), Gomes and Michaelides (2005), Gomes et al. (2004), Lynch and Tan (2004), Polkovnichenko (2007), Roussanov (2004), Willen (2003), Yao and Zhang (2005), and Benzoni et al. (2005). These life cycle models of portfolio choice form a branch of the more general literature on dynamic portfolio choice which has evolved from the seminal contributions by Samuelson (1969), Merton (1969) and Merton (1971). Partial surveys of this more general literature are e.g. JaGanNathan and KocherLaKota (1996), Heaton and Lucas (2000), Campbell and Viceira (2002) or Klos et al. (2003). See WallMEIER and Zainhofer (2006) for a detailed review of life cycle models of portfolio choice.

3 See e.g. Haliassos and Michealides (2002). 
earnings trajectories and earnings variances of stylized Swiss investors. We then feed the empirical results into a computational life cycle model of portfolio choice recently suggested by Cocco et al. (2005) to examine the implied investment differences and their determinants. Using a finer classification of investor types than in previous studies, we hope to extract information about how one type should invest in relation to the other types.

The paper is organised as follows: section 2 describes set-up and solution of the life cycle model of portfolio choice used in the analysis. This is followed by the empirical analysis of section 3 . We conclude by analysing the normative implications of the Swiss data for life cycle portfolio choice in section 4 .

\section{A Life Cycle Model of Portfolio Choice}

In this section, we describe set-up and solution of the life cycle model of portfolio choice by Cocco et al. (2005) used in subsequent analyses.

The investor is assumed to have a finite horizon $T$ and to be concerned about her expected discounted lifetime utility derived from consumption. Taking into account a realistic survival process, expected utility can be written as: ${ }^{4}$

$$
E_{0} \sum_{t=1}^{T} \beta^{t}\left(\prod_{j=0}^{t-1} \psi_{j+11 j}\right) u\left(C_{t}\right)
$$

where $\beta$ is the discount factor, $u(\bullet)$ a standard power utility function,

$$
u\left(C_{t}\right)=\frac{C_{t}^{1-\gamma}}{1-\gamma},
$$

$C_{t}$ periodic consumption and $\psi_{t+1 \mid t}$ the probability to survive up to period $t+1$ conditional on having survived up to period $t .{ }^{5}$ The investor begins to work at time $t_{0}$ and retires at time $t_{R}$. During working life, she receives exogenous labor income $Y_{t}$ with $y_{t} \equiv \log Y_{t}$ modelled as the sum of a permanent component $f\left(t, \mathbf{Z}_{t}\right)+v_{t}$ and a transitory shock $\varepsilon_{t}$ :

$$
y_{t}=f\left(t, Z_{t}\right)+v_{t}+\varepsilon_{t}, \forall t: t_{0} \leq t \leq t_{R} .
$$

4 We abstract from bequests. See e.g. Cocco et al (2005) for an analysis of the effects.

$5 E_{t}$ denotes expectation conditional on time $t$ information. 
The permanent component consists of a deterministic function $f(t, \mathbf{Z})$ of age and individual characteristics $\mathbf{Z}_{t}{ }^{6}$ and of a persistent income component $v_{t}$ that follows a random walk:

$$
v_{t}=v_{t-1}+u_{t} \text {. }
$$

Both $\varepsilon_{t}$ and $u_{t}$ are assumed to be iid normally distributed with mean zero and variances $\sigma_{\varepsilon}^{2}$ and $\sigma_{u}^{2}$, respectively?

Retirement income is exogenously specified as a constant fraction $\lambda$ of the permanent component of labor income in the retirement year $t_{R}$ :

$$
y_{t}=\log \lambda+\left(f\left(t_{R}, Z_{t_{R}}\right)+v_{t_{R}}\right) \forall t>t_{R} .
$$

The investor starts any given period $t$ with accumulated financial wealth $W_{t}$ and realizes labor income $Y_{t}$. Together, $W_{t}$ and $Y_{t}$ make up all resources available for consumption. These resources are usually denominated cash-on-hand $\left(X_{t}\right)$ :

$$
X_{t} \equiv W_{t}+Y_{t}
$$

Next, the investor consumes the desired amount $C_{t}$. Any remaining resources (savings) are credited to the savings account. The investor can then decide on the fraction of savings to be invested in a risky asset $\left(\alpha_{t}\right)$, while the remainder $\left(1-\alpha_{t}\right)$ is invested in a riskless asset. The riskless asset has known, constant gross return $R_{r f}$. The risky asset's return, $R_{e, t+1}$, is given by the riskless rate plus a risk premium $\kappa$ disturbed by a white noise shock $\zeta_{t}$ :

$$
R_{e, t+1}=R_{r f}+\kappa+\zeta_{t+1}
$$

The investor's asset allocation and asset returns result in a compound portfolio return of

$$
\begin{aligned}
R_{p, t+1} & \equiv \alpha_{t} R_{e, t+1}+\left(1-\alpha_{t}\right) R_{r f} \\
& =\alpha_{t}\left(\kappa+\zeta_{t+1}\right)+R_{r f} .
\end{aligned}
$$

6 The dimensionality of $Z_{t}$ depends on the number of individual characteristics considered.

7 This specification is also common in the literature on life cycle saving. See e.g. Hubbard et al. (1995), Carroll and Samwick (1997), Gourinchas and Parker (2002). 
The dynamics of financial wealth can then be summarized as:

$$
W_{t+1}=\left(W_{t}+Y_{t}-C_{t}\right) R_{p, t+1} .
$$

Using (6), this equation can also be re-written in terms of cash-on-hand as:

$$
X_{t+1}=\left(X_{t}-C_{t}\right) R_{p, t+1}+Y_{t+1} \text {. }
$$

In summary, the investor controls her consumption

$$
\left\{C_{t}\right\}_{t=t_{0}}^{T-1} \text { as well as her risky asset share }\left\{\alpha_{t}\right\}_{t=t_{0}}^{T-1}
$$

throughout lifetime, subject to three sources of uncertainty, the labor income shocks $\varepsilon_{t}$ and $u_{t}$ and the stock return shock $\zeta_{t}{ }^{8}$ The investor's optimization problem can be stated as:

$$
\begin{aligned}
& \max _{\left.\left\{\alpha_{t}\right\}_{t=t_{0}}^{T-\left\{C_{t}\right.}\right\}_{t=t_{0}}^{T+1}} \text { (1) s.t. (2), (3), (4), (5), (8), (10) } \\
& 0 \leq a_{t} \leq 1,0 \leq C_{t} \leq X_{t} \text { and } X_{0} \text { given. }
\end{aligned}
$$

Notice from (11) that the optimization is subject to the standard inequality constraints $0 \leq \alpha_{t} \leq 1$ (i.e. the risky asset can neither be sold short nor can the investment in the risky asset be levered up) and $0 \leq C_{t} \leq X_{t}$ (i.e. consumption is bounded from above by cash-on-hand).

As is well known, a solution to problem (11) is a function (the policy function) that specifies the optimal time paths for the control variables

$$
\left\{\alpha_{t}^{*}\right\}_{t=t_{0}}^{T-1} \text { and }\left\{C_{t}^{*}\right\}_{t=t_{0}}^{T-1} \text {, }
$$

depending on the problem's state variables, time $t$, cash-on-hand $X_{t}$ and the random walk component of labor income $v_{t}$. The state space can be reduced to the two variables $t$ and $X_{t}$ by standardizing the entire problem by the permanent component of labor income $f\left(t, \mathbf{Z}_{t}\right)+v_{t}{ }^{9}$ 
In the present case, the policy functions cannot be obtained analytically, but must be approximated numerically. The approximation is based on a recursive representation of the problem by means of the 'Bellman Equation'. Denoting by $V_{t}(\bullet)$ the value function, this equation can be written as:

$$
\begin{gathered}
V_{t}\left(X_{t}\right)=\max _{0 \leq C_{t} \leq X_{t}, 0 \leq \alpha_{t} \leq 1}\left\{u\left(C_{t}\right)+\psi_{t+1 \mid t} \beta E_{t}\left[V_{t+1}\left(X_{t+1}\right)\right]\right\} \\
\text { s.t. (10), (2), (3), (4), (5), (8), } X_{0} \text { given. }
\end{gathered}
$$

In the last period $(T)$, it is optimal to consume all remaining resources, which implies that the value function corresponds to the instantaneous utility function: $V_{T}\left(X_{T}\right)=u\left(X_{T}\right)$. The problem can then be solved by backward induction starting in $T-1 .^{10}$

We solve the model for the following parameter settings: $\kappa=0.03, \sigma_{\xi}=20.25 \%$, $R_{r f}=2.1 \%{ }^{11}$ Also $\gamma=5, \beta=0.96, t_{0}=20\left(t_{0}=25\right.$ for highly educated individuals), $t_{R}=65$ and $T=95$. Swiss survival probabilities were obtained for the year 2001/2002 from the Swiss Federal Office of Statistics (FOS). Baseline replacement rates $(\lambda)$ were obtained from the $O E C D$ for Switzerland. ${ }^{12}$ This data describes the replacement rate an individual can expect from the mandatory pension scheme as a function of gender and individual earnings level. ${ }^{13}$ Three different levels of individual earnings are reported (relative to average earnings): i.) one half, ii.) one and iii.) two times average earnings. Specifically, the baseline rates used for women are: i.) $71.6 \%$, ii.) $68 \%$, iii.) $41.8 \%$. Those used for men are: i.) $71.4 \%$, ii.) $67.3 \%$, iii.) $41.4 \% .^{14}$

Having obtained the policy functions, we follow standard practice and trace out realistic representative life cycle consumption and asset allocation profiles by simulating 10.000 time series of the random variables

$$
\left\{\zeta_{t}\right\}_{i, t=0}^{T}\left\{\varepsilon_{t}\right\}_{i, t=0}^{t_{R}} \text { and }\left\{u_{t}\right\}_{i, t=0}^{t_{R}} .
$$

10 We cannot further elaborate on the solution here. Details are available from the author. See e.g. Carroll (2002) for methods to solve similar problems.

11 These parameter settings correspond to empirical results derived from Swiss data by Drobetz (2000).

12 The data is freely downloadable from the OECD's website.

13 Specifically, it is defined as "individual pension entitlement net of taxes and contributions as a percentage of individual pre-retirement earnings net of taxes and contributions".

14 Alternative replacement rate scenarios are considered in section 3 below. 
For every simulated set of time series, the policy functions are then evaluated at the actually relevant points in the state space to obtain optimal life cycle profiles for all variables of interest. These are finally averaged at every point in time to obtain representative life cycle profiles. ${ }^{15}$

\section{Empirical Analysis of Swiss Labor Income Dynamics}

In this section, an empirical analysis using Swiss data is performed to obtain realistic estimates for the parameters of the labor income process (3)-(4) employed in section 2's portfolio choice model. Specifically, estimates are sought for the deterministic component of labor income, $f\left(t, \mathrm{Z}_{t}\right)$ in (3), as well as for the variances of transitory and permanent labor income shocks, $\sigma_{\varepsilon}^{2}$ and $\sigma_{u}^{2}$, respectively. We first relate our empirical analysis to the existing literature. Then the empirical model and estimation method are briefly sketched. This is followed by a presentation of the data and a discussion of the results.

\subsection{Related Literature}

Earnings functions date back to the seminal work of Mincer (1974) and have a long tradition in empirical labor economics. ${ }^{16}$ Several researchers have estimated extensions of classic wage functions with Swiss data, comprising such issues as gender discrimination with respect to wages (DiEkMANN and ENGELHARDT, 1994; Bonjour and Gerfin, 1995; Henneberger and Sousa-Poza, 1998; Bonjour, 1997; Flueckiger and Ahmad, 1996 ${ }^{17}$ ), the effects of immigration on wages (KüNG, 2005; SHELDON, 2000), wage differentials between native and nonnative speakers (CATTANEO and WinkELmanN, 2003), the values of different countries education systems (GRUETTER, 2005), returns to tenure (LuCHSINGER et al., 2001), selection biases in wage functions estimated from SLFS data (Sousa-Poza and Henneberger, 1998; Sousa-Poza and Henneberger, 2000), life cycle aspects of income (ZURBRÜGG, 1990), nonparametric estima-

15 Model solution and simulations are performed using a Mathematica routine developed by the author. Details are available upon request.

16 See CHIswick (forthcoming) for a detailed review of the Mincer equation's origins, development and impact. See e.g. Polachex and Siebert (1993), chapter 4.4 for extensions of the basic function. Lemieux (forthcoming) argues that, with minor adjustments, the Mincer equation remains a robust econometric model today.

17 The last two are cited indirectly through Sousa-Poza and Henneberger (1998). 
tion of income-age functions (Gerfin, 1994) and issues of income inequality (ERnst et al., 2000).

However, the primary interest of these Swiss studies was not to estimate ageearnings profiles. Additionally, the studies by Gerfin and others measure income by annual disposable household income which already includes asset income and are thus not applicable to a portfolio choice study where asset income is endogenous. Finally, the studies do not employ empirical models with dynamic error components such as that we wish to estimate.

The latter type of model was introduced by Lillard and Willis (1978), WeIss and Lillard (1978), Lillard (1977), Hause (1977), and Lillard and Weiss (1979) who used longitudinal US data and a richer error autocovariance to separate permanent from transitory effects and to analyse life cycle dynamics of the earnings distribution. ${ }^{18}$ Our empirical model is a closely related variant of these early 'longitudinal earnings models' as shall be described now.

\subsection{Empirical Model and Estimation Method}

The problem is to estimate a specific implementation of (3) and (4) from panel data. We choose a simple linear model:

$$
y_{i t}=\mathbf{z}_{i t}^{\prime} \beta+\eta_{i t},
$$

for $i=1,2, \ldots, N, t=1,2, \ldots, T$, and with

$$
\eta_{i t} \equiv v_{i t}+\varepsilon_{i t}
$$

and $v_{i t}$ given by (4). $\mathbf{z}_{i t}$ is a $K \times 1$ vector of explanatory variables, consisting of a variable for the number of household members, age dummies and dummies for marital status. ${ }^{19}$ We want to estimate $\beta$ and the variances $\sigma_{\varepsilon}^{2}$ and $\sigma_{u}^{2}$.

18 See also MACurdy (1981) and MACurdy (1982) for a review of the functional forms used in this literature.

$19 z_{i t}$ could also contain additional 'control' variables. However, we control for gender, education and activity rate using sample splits. See section 3.3 below for details. Also, Hubbard et al. (1994) argue that including a cross section specific, time invariant fixed effect, say $\delta_{i}$, in (13) is not necessary because splitting the sample by education would already control for the heterogeneity effect. They also argue that - with $\delta_{i}$ present - one would have to solve the theoretic model for every fixed effect, which is computationally burdensome if not impossible.

20 It is a special case because the order of the MA process of our transitory component $\varepsilon_{i t}$ is zero as compared to the MA(2) process in HaLL and Mishrin (1982). 
This problem is a special case of that entertained by HALL and MishKin (1982). ${ }^{20}$ Estimation proceeds in two steps: in a first step one obtains consistent estimates for $\beta$ and $\eta_{i t}, \hat{\beta}$ and $\hat{n}_{i t}$, via standard pooled OLS estimation. ${ }^{21}$ In a second step one then uses the $\hat{n}_{i t}$ to estimate $\sigma_{\varepsilon}^{2}$ and $\sigma_{u}^{2},{ }^{22}$ making use of the restrictions placed on a particular covariance matrix by the time series model for $\eta_{i t}$, (14) and (4). We follow this method and use the maximum likelihood estimator suggested by Arellano (2003) to estimate the variances in the second step. $^{23}$

To derive a smoothed functional form that can be used for the function $f\left(t, \mathbf{Z}_{t}\right)$ in equation (3) of the portfolio choice model, we fit third and fifth order polynomials in age to the mean fitted values from (13). ${ }^{24}$

\subsection{Data and Descriptives}

We use data from the SLFS administered by the FOS. In the SLFS some 16.00018.000 individuals are surveyed annually on a large number of items. Every year $20 \%$ of the individuals are replaced. Thus, the time series component of the panel is at most 5 years because one individual contributes at most 5 consecutive datapoints on an item. The panel is unbalanced as an individual can choose not to answer the survey anymore at any time. We have available SLFS data for all years from 1991-2000.

The following preliminary manipulations are performed on the raw data: we construct a new coarse education variable by reclassifying the answer choices of existing education variables "bqu1" (1991) and "bqu2" (1992-2000) into the three categories 'elementary', 'secondary' and 'higher' education. Next, we define dummies for all ages from 20 to 65 , as well as dummies for being single, married,

21 See e.g. Hall and Mishrin (1982), Lillard and Willis (1978), Lillard and Weiss (1979), Hubbard et al. (1994), and MaCurdy (1982).

22 Having estimated $\hat{\sigma}_{u}^{2}$ and $\hat{\sigma}_{\varepsilon}^{2}$, one could go back to step 1 and re-estimate $\beta$ by GLS. We abstract from this additional complexity because we are content with a consistent estimate of $\beta$.

23 See Arellano (2003), pp.68-69. An alternative, but less general estimation method that works only in the particular case of (14) and (4) is suggested by CARROLL and SAMWICK (1997) and is used by Cocco et al (2005). Further details of the estimation are spared for brevity, but are available from the author upon request.

24 See Cocco et al (2005).

25 "iw14" includes capital income and is thus not suitable. "bwu1" measures individual annual gross (i.e. before contributions to social security) labor income, a quantity that is not actually investable or consumable, and can thus also not be used. 
divorced and widowed. "bwu2" is used as the labor income proxy. ${ }^{25}$ We detrend it to the reference year 1991 using a Swiss consumer price index ("Landesindex der Konsumentenpreise") obtained from the FOS. ${ }^{26} \mathrm{~A}$ problem with our labor income variable ("bwu2") is that the unemployed report "not applicable" for this variable. This means that they would automatically be dis-selected from the samples during the estimations for not disposing of labor income observations. To attenuate the potentially arising selection bias, we construct an unemployment benefit proxy ${ }^{27}$ and assign it to the unemployed as their 'labor income'-observation. ${ }^{28}$

From all observations in the entire sample we select only those observations where survey respondents are aged between 20 and 65, are not apprentices, recruits, in education, housewives or housemen, retirees or not part of the workforce for other reasons and where they did not specify "not applicable", "not reported", "do not know" or "unclassifiable" for their labor market- nor for their marital status. The resulting sample was then split by gender and education yielding six 'baseline' subsamples: elementary, secondary and high education for both females and males. In order to analyse robustness of our results, we also consider a total of 42 additional subsamples obtained from the six basic samples by controlling for employment status, the considered age-ranges and activity rate. More specifically, all estimations are performed on the six 'baseline' subsamples altered by excluding the self-employed, truncating the age-range (e.g. 25-60 instead of 20-65), doing both simultaneously and by repeating all of the previous for full-time workers only.

The missing values in the second estimation step are imputed using a multiple imputation routine for normal data and multidimensional estimands described by SCHAFER (1997). ${ }^{29}$

All basic subsamples are dominated by married individuals, although in the female higher education sample there are almost as many observations from singles as from married women. The divorced carry relatively more weight in female as compared to male subsamples. These observations on marital status hold equally for the entire sample and if the self-employed are removed. When part-time workers are excluded, the distribution of marital status remains unaltered in the male

26 The total index can be downloaded for different base years under: http:/ /www.bfs. admin.ch/ $\mathrm{bfs} / \mathrm{portal} / \mathrm{de} /$ index/ themen/ preise/ konsumentenpreise/ landesindex/ kennzahlen/ multibasis. html

27 To our knowledge, there is no such variable available in the SLFS.

28 Prior labor income serves as an estimate of the AVIG/AVIV insured salary which is used to compute unemployment benefits. Where prior labor income is not available, AVIG/AVIV flat rates are used. Further details are available from the author upon request.

29 Details are available from the author upon request. 
sub-samples, but there is now a clear dominance of single over married women in the secondary and high education groups. In other words, a majority of fully employed women with more than elementary education are singles. In all subsamples employees are by far the strongest group with respect to the number of contributed observations. ${ }^{30}$

The chosen approach to construct coarse education groups produces a large number of secondary education graduates (Tables 1 and 2). In the entire sample (Table 1), mean and median log labor income rise with education for both males and females, but are higher for males than for females in every education subgroup. When we remove the self-employed, the standard deviation of log labor income decreases slightly for all education groups and independent of gender while the prior observations remain valid. The standard deviation of womens' log labor income is higher than that of mens' across all education samples and independent of whether the self-employed are excluded or not.

In the male samples, the number of observations drops only slightly when part-time workers are excluded (Table 2). In the female samples however, the number of observations drops by about $50 \%$ in every sub-sample. This means that around one half of all observations in a given baseline female sample are from part-time workers. Across all sub-samples mean and median log labor income rise while the standard deviation of log labor income declines when parttime workers are excluded. Regarding the qualitative behavior of mean, median and standard deviation of log labor income as a function of gender, education and employment status (employees only vs. employees and self-employed) we make identical observations as in Table 1.

30 Corresponding figures are not reported, but are available from the author upon request. 
Table 1: Descriptive Statistics Part-time and Full-time Workers

\begin{tabular}{|c|c|c|c|c|c|c|}
\hline Variable & Mean & Median & Max. & Min. & Std. Dev. & Obs. \\
\hline & \multicolumn{6}{|c|}{ Employees and self-employed } \\
\hline & \multicolumn{6}{|c|}{ A: Females, higher education } \\
\hline Log labor income & 10.69 & 10.83 & 15.78 & 5.83 & 0.76 & 3,067 \\
\hline No. hh members & 2.29 & 2.00 & 8.00 & 1.00 & 1.27 & 3,067 \\
\hline \multirow[t]{2}{*}{ Age } & 38.79 & 37.00 & 65.00 & 25.00 & 9.14 & 3,067 \\
\hline & \multicolumn{6}{|c|}{ B: Females, secondary education } \\
\hline Log labor income & 10.19 & 10.44 & 14.48 & 2.45 & 0.88 & 32,077 \\
\hline No. hh members & 2.39 & 2.00 & 10.00 & 1.00 & 1.26 & 32,077 \\
\hline \multirow[t]{2}{*}{ Age } & 38.08 & 36.00 & 65.00 & 20.00 & 11.15 & 32,077 \\
\hline & \multicolumn{6}{|c|}{ C: Females, low education } \\
\hline Log labor income & 9.78 & 9.98 & 13.65 & 4.39 & 0.89 & 7,716 \\
\hline No. hh members & 2.51 & 2.00 & 8.00 & 1.00 & 1.24 & 7,716 \\
\hline \multirow[t]{2}{*}{ Age } & 43.62 & 44.00 & 65.00 & 20.00 & 11.61 & 7,716 \\
\hline & \multicolumn{6}{|c|}{ D: Males, higher education } \\
\hline Log labor income & 11.25 & 11.31 & 14.91 & 5.51 & 0.64 & 5,883 \\
\hline No. hh members & 2.61 & 2.00 & 8.00 & 1.00 & 1.40 & 5,883 \\
\hline \multirow[t]{2}{*}{ Age } & 40.96 & 40.00 & 65.00 & 25.00 & 9.91 & 5,883 \\
\hline & \multicolumn{6}{|c|}{ E: Males, secondary education } \\
\hline Log labor income & 10.91 & 10.94 & 16.22 & 2.63 & 0.55 & 39,352 \\
\hline No. hh members & 2.65 & 2.00 & 9.00 & 1.00 & 1.35 & 39,352 \\
\hline \multirow[t]{2}{*}{ Age } & 39.20 & 38.00 & 65.00 & 20.00 & 11.22 & 39,352 \\
\hline & \multicolumn{6}{|c|}{ F: Males, low education } \\
\hline Log labor income & 10.59 & 10.69 & 13.78 & 6.30 & 0.55 & 4,779 \\
\hline No. hh members & 2.78 & 3.00 & 9.00 & 1.00 & 1.36 & 4,779 \\
\hline Age & 42.07 & 41.00 & 65.00 & 20.00 & 11.69 & 4,779 \\
\hline
\end{tabular}


Table 1 (continued)

\begin{tabular}{|c|c|c|c|c|c|c|}
\hline Variable & Mean & Median & Max. & Min. & Std. Dev. & Obs. \\
\hline & \multicolumn{6}{|c|}{ Employees only } \\
\hline & \multicolumn{6}{|c|}{ G: Females, higher education } \\
\hline Log labor income & 10.69 & 10.83 & 15.78 & 5.83 & 0.72 & 2,726 \\
\hline No. hh members & 2.24 & 2.00 & 7.00 & 1.00 & 1.24 & 2,726 \\
\hline \multirow{2}{*}{ Age } & 38.21 & 37.00 & 65.00 & 25.00 & 9.04 & 2,726 \\
\hline & \multicolumn{6}{|c|}{ H: Females, secondary education } \\
\hline Log labor income & 10.22 & 10.47 & 14.12 & 2.47 & 0.85 & 29,569 \\
\hline No. hh members & 2.36 & 2.00 & 9.00 & 1.00 & 1.24 & 29,569 \\
\hline \multirow[t]{2}{*}{ Age } & 37.74 & 36.00 & 65.00 & 20.00 & 11.12 & 29569 \\
\hline & \multicolumn{6}{|c|}{ I: Females, low education } \\
\hline Log labor income & 9.79 & 9.98 & 13.65 & 4.39 & 0.87 & 7,300 \\
\hline No. hh members & 2.50 & 2.00 & 8.00 & 1.00 & 1.23 & 7,300 \\
\hline \multirow[t]{2}{*}{ Age } & 43.48 & 44.00 & 65.00 & 20.00 & 11.61 & 7,300 \\
\hline & \multicolumn{6}{|c|}{ J: Males, higher education } \\
\hline Log labor income & 11.23 & 11.30 & 14.74 & 5.51 & 0.61 & 4,900 \\
\hline No. hh members & 2.54 & 2.00 & 8.00 & 1.00 & 1.38 & 4,900 \\
\hline \multirow[t]{2}{*}{ Age } & 40.25 & 38.00 & 65.00 & 25.00 & 9.89 & 4,900 \\
\hline & \multicolumn{6}{|c|}{ K: Males, secondary education } \\
\hline Log labor income & 10.91 & 10.94 & 16.22 & 2.63 & 0.52 & 33,734 \\
\hline No. hh members & 2.60 & 2.00 & 9.00 & 1.00 & 1.33 & 33,734 \\
\hline \multirow[t]{2}{*}{ Age } & 38.56 & 37.00 & 65.00 & 20.00 & 11.21 & 33,734 \\
\hline & \multicolumn{6}{|c|}{ L: Males, low education } \\
\hline Log labor income & 10.59 & 10.70 & 13.78 & 6.30 & 0.53 & 4,280 \\
\hline No. hh members & 2.76 & 3.00 & 9.00 & 1.00 & 1.33 & 4,280 \\
\hline Age & 41.65 & 41.00 & 65.00 & 20.00 & 11.66 & 4,280 \\
\hline
\end{tabular}


Table 2: Descriptive Statistics Full-time Workers Only

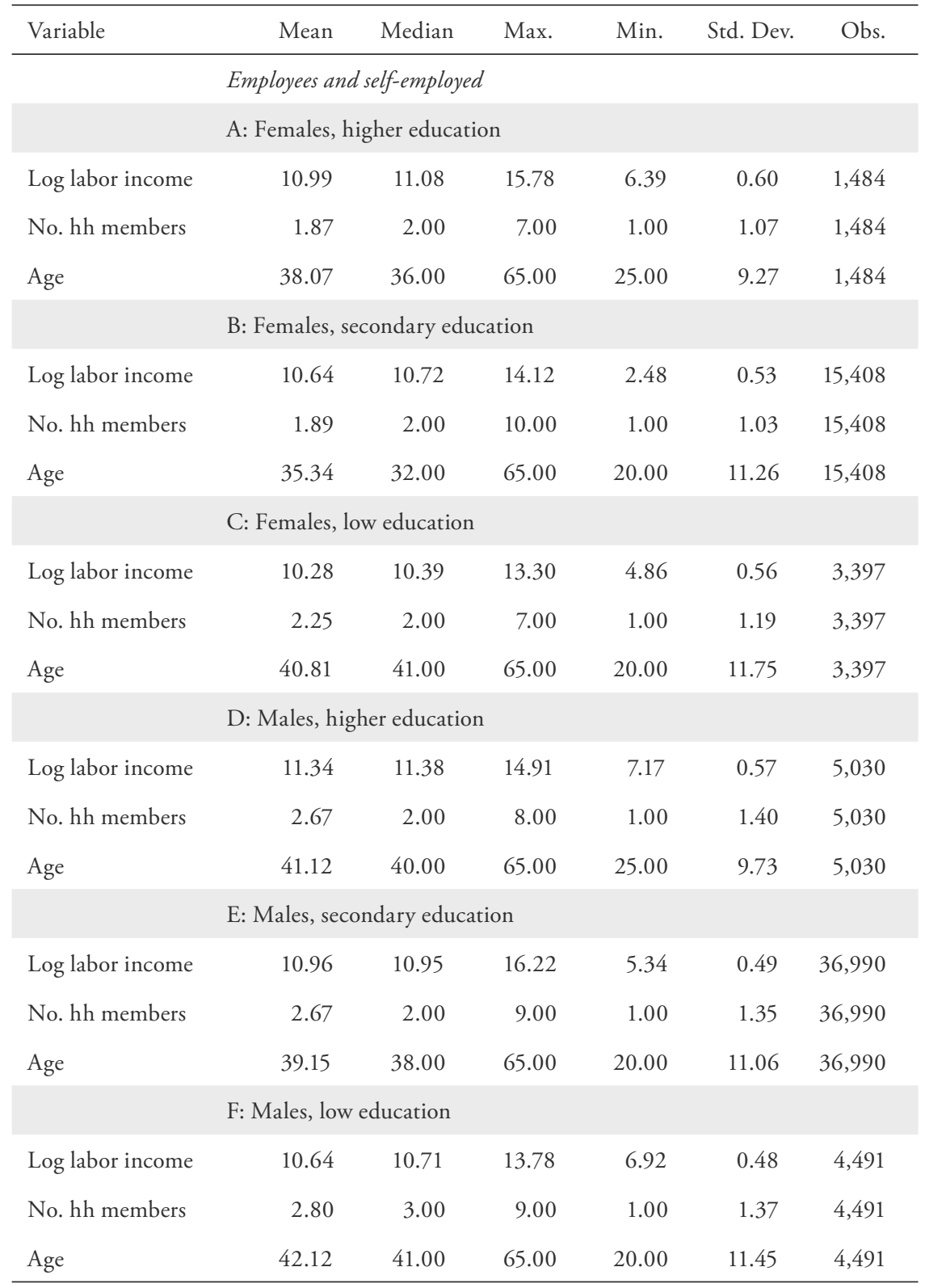


Table 2 (continued)

\begin{tabular}{|c|c|c|c|c|c|c|}
\hline Variable & Mean & Median & Max. & Min. & Std. Dev. & Obs. \\
\hline & \multicolumn{6}{|c|}{ Employees only } \\
\hline & \multicolumn{6}{|c|}{ G: Females, higher education } \\
\hline Log labor income & 10.98 & 11.08 & 15.78 & 6.39 & 0.57 & 1,332 \\
\hline No. hh members & 1.83 & 2.00 & 6.00 & 1.00 & 1.05 & 1,332 \\
\hline \multirow[t]{2}{*}{ Age } & 37.48 & 35.00 & 64.00 & 25.00 & 9.19 & 1,332 \\
\hline & \multicolumn{6}{|c|}{ H: Females, secondary education } \\
\hline Log labor income & 10.65 & 10.72 & 14.12 & 2.48 & 0.50 & 14,340 \\
\hline No. hh members & 1.87 & 2.00 & 9.00 & 1.00 & 1.01 & 14,340 \\
\hline \multirow[t]{2}{*}{ Age } & 34.80 & 32.00 & 65.00 & 20.00 & 11.06 & 14,340 \\
\hline & \multicolumn{6}{|c|}{ I: Females, low education } \\
\hline Log labor income & 10.28 & 10.39 & 11.73 & 4.86 & 0.55 & 3,200 \\
\hline No. hh members & 2.24 & 2.00 & 7.00 & 1.00 & 1.18 & 3,200 \\
\hline \multirow[t]{2}{*}{ Age } & 40.53 & 40.00 & 65.00 & 20.00 & 11.73 & 3,200 \\
\hline & \multicolumn{6}{|c|}{ J: Males, higher education } \\
\hline Log labor income & 11.32 & 11.36 & 14.74 & 7.17 & 0.54 & 4,166 \\
\hline No. hh members & 2.59 & 2.00 & 8.00 & 1.00 & 1.38 & 4,166 \\
\hline \multirow[t]{2}{*}{ Age } & 40.43 & 39.00 & 65.00 & 25.00 & 9.75 & 4,166 \\
\hline & \multicolumn{6}{|c|}{ K: Males, secondary education } \\
\hline Log labor income & 10.96 & 10.95 & 16.22 & 5.34 & 0.44 & 31,729 \\
\hline No. hh members & 2.63 & 2.00 & 9.00 & 1.00 & 1.33 & 31,729 \\
\hline \multirow[t]{2}{*}{ Age } & 38.55 & 37.00 & 65.00 & 20.00 & 11.07 & 31,729 \\
\hline & \multicolumn{6}{|c|}{ L: Males, low education } \\
\hline Log labor income & 10.64 & 10.71 & 13.78 & 6.92 & 0.45 & 4,034 \\
\hline No. hh members & 2.79 & 3.00 & 9.00 & 1.00 & 1.34 & 4,034 \\
\hline Age & 41.70 & 41.00 & 65.00 & 20.00 & 11.43 & 4,034 \\
\hline
\end{tabular}




\subsection{Empirical Results}

\subsubsection{Life Cycle Labor Income Trajectories}

Figure 1 exhibits the estimated labor income-age profiles together with fitted polynomials for the 'baseline' samples. ${ }^{31}$ The male profiles are similar to previous results, e.g. by Mincer (1974) $)^{32}$ and Cocco et al. (2005) ${ }^{33}$ and in agreement with theoretic arguments as outlined e.g. in PolacheK and Siebert (1993).

Similar to the male profiles, the general earnings level of females rises with education. However, we also observe some salient differences compared to the male profiles: female profiles are not monotonically concave. Rather, the initial increase in labor income is followed by a trough and subsequently a second peak. The first peak is reached later in higher education groups. Also, the increase following the trough is significantly more pronounced for the highly educated as compared to the elementary and secondary education groups. Additionally, we note that the general labor income variation is lower for females than for males.

To analyse this finding further, we control for the investor's activity rate. Figure 2 presents otherwise identical age-earnings profiles with part-time workers excluded. For men, results are very similar to the 'baseline case'. Thus, male part-time employment does not appear to be an empirically relevant phenomenon and we discard this possibility for our portfolio choice analysis. For women however, the opposite is true: when excluding part-time workers from the female samples, we obtain age-earnings profiles similar to those of men, although less peaked. The 'troughs' characteristic of the joint sample effectively disappear and concavity obtains. Thus, the earnings 'throughs' in the combined female samples can be explained by the presence of a substantial fraction of part-time workers with reduced earnings during these ages.

\subsubsection{Transitory and Permanent Variances}

Table 3 exhibits estimates for $\sigma_{\varepsilon}^{2}$ and $\sigma_{u}^{2}$, derived from the combined sample of part-time and full-time workers, as well as related results by Cocco et al. (2005) for the US. ${ }^{34}$ Cocco et al. (2005) find that transitory variance is an order of mag-

31 These results remain essentially unchanged if the self-employed are excluded. Corresponding figure not reported.

32 See e.g. his results on white, nonfarm men on p.66.

33 However, the results of Cocco et al (2005) are estimated from household data, not from individual data as used here! 
Figure 1: Age-earnings Trajectories

A: Females

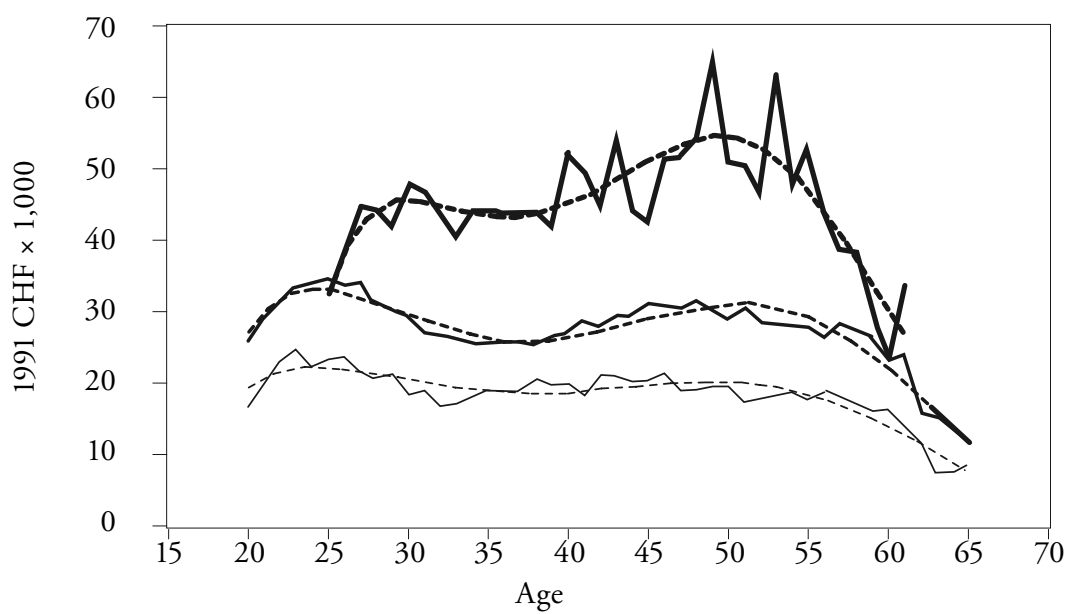

B: Males
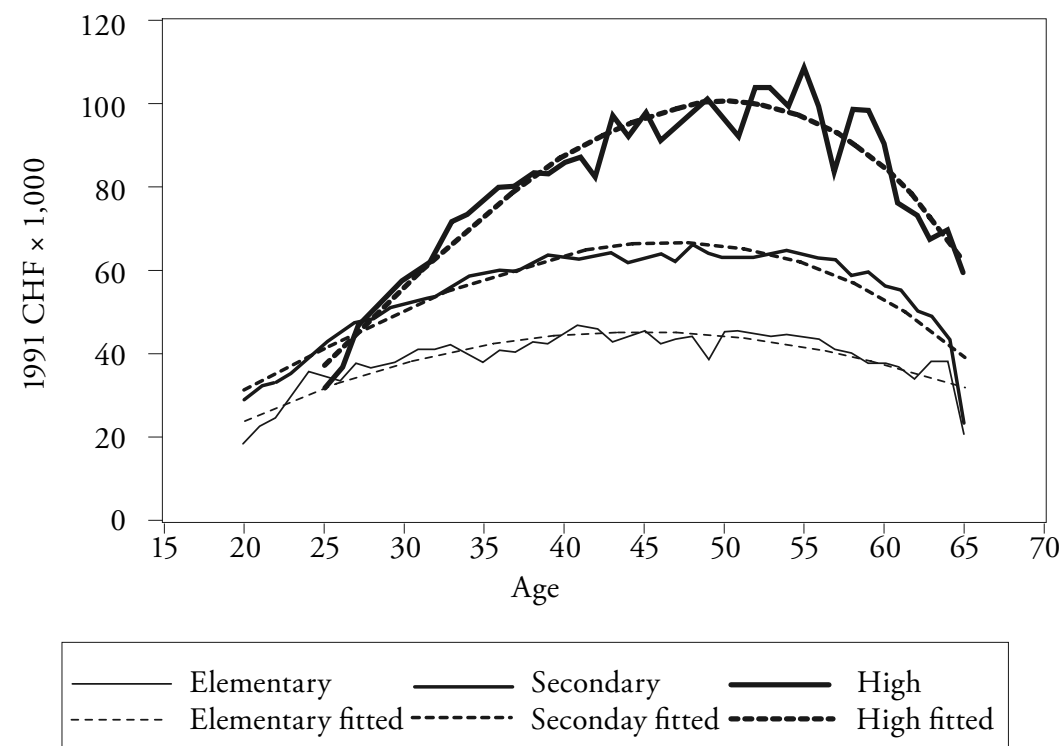

This figure shows mean fitted values from the first stage regression as a function of age as well as fitted third-order (men) and fifth-order (women) polynomials. 
Figure 2: Age-earnings Trajectories, Full-time Workers Only.

A: Females

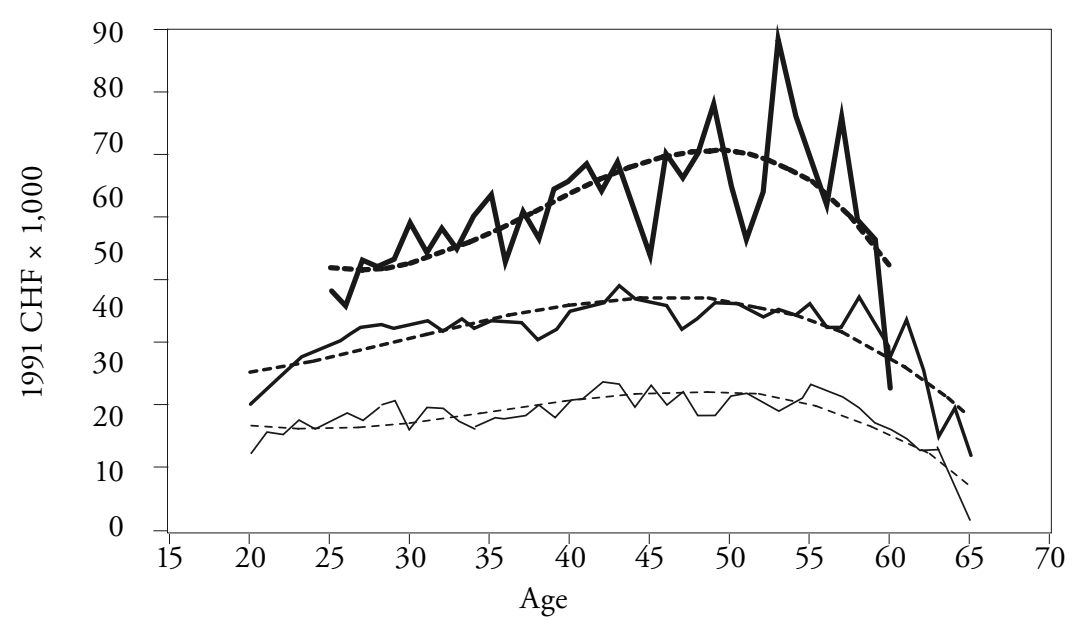

B: Males

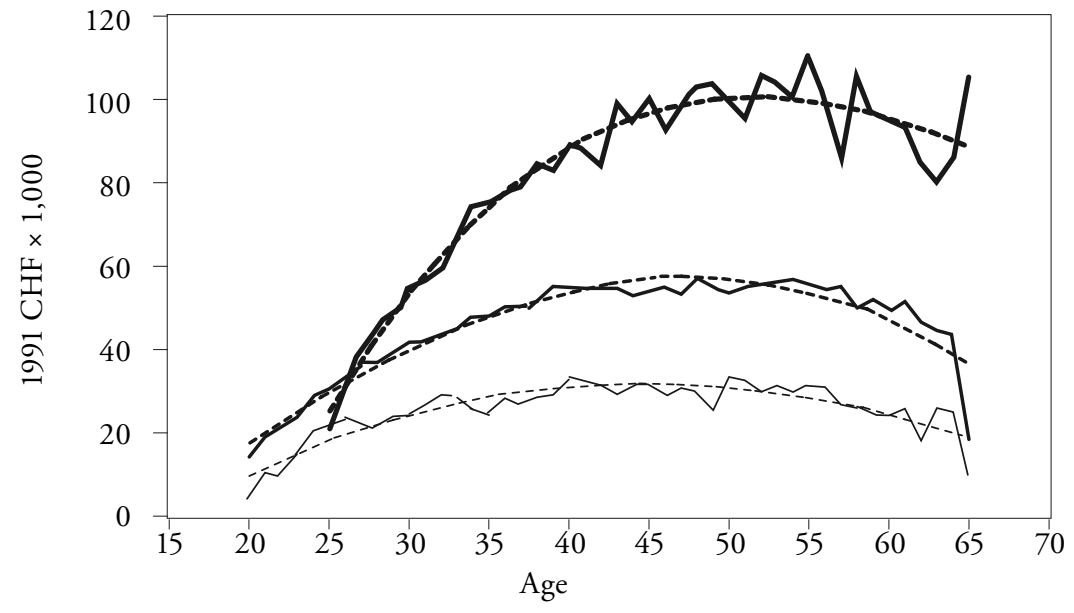

Elementary

Secondary

High

Elementary fitted -...-.-.. Seconday fitted -...-.-. High fitted

This figure shows mean fitted values from the first stage regression as a function of age, as well as fitted third-order polynomials. 
nitude greater than permanent variance across all of their three education groups. Households with highly educated heads are found to have the lowest transitory but the highest permanent income variance, whereas households with little educated heads display the converse result.

Consider now our baseline results (Table 3, first panel): as in Cocco et al. (2005), transitory income variances are found to be an order of magnitude greater than permanent income variances across all subsamples. In the male samples, transitory variance is an increasing function of education, whereas in the female subsample the reverse is true. Women are found to have larger transitory variances than men. We find permanent variances to exceed the estimates of Cocco et al. (2005) for all of our subsamples with the exception of men with secondary education. Women are found to have substantially larger permanent variances than men. We also observe that secondary education graduates have the lowest permanent income variance, independent of gender. ${ }^{35}$

Table 4 exhibits variance estimates obtained from samples of fully employed individuals only. The findings for men are in line with previous results. Women, however no longer have unambiguously higher transitory and permanent variances than men. In fact it seems as if this previous observation has reversed (Table 4, first panel). In the male case, both transitory and permanent variances are now estimated to be around one to two percentage points lower than in the combined part-time / full-time sub-samples (Table 4 vs. Table 3). In the female case, too, variances are estimated to be lower, but whereas permanent and transitory variances of women with high education drop only by around two percentage points each, transitory variances of women with secondary or elementary education are reduced by close to eight percentage points while their permanent variances are now estimated to be essentially zero. ${ }^{36}$ The 'baseline' results in the fully employed sub-samples, too, are robust against excluding the self-employed, truncating age ranges and doing both simultaneously (remaining panels in Table 4). ${ }^{37}$

34 Our results are not directly comparable to theirs because they analyse total household labor income, whereas we consider individual income. Also, their labor income variable might comprehend particular public transfers not included in our labor income proxy.

35 Excluding the self-employed from the estimation (Table 3, second panel) or estimating the baseline samples on truncated age ranges (Table 3, third panel) yields similar results. As expected, variance estimates are generally lower when the self-employed are excluded.

36 The variance reductions observed when part-time workers are excluded come to a certain extent expected: income variability is higher in the combined samples than in the fully-employed samples as part-time workers earn less than full-time workers.

37 All results in this section also prove robust in a different variant of the multiple imputation routine. 
Table 3: Permanent and Transitory Labor Income Shocks

This figure shows results from estimating $\sigma^{2}$ and $\sigma^{2}$ by the maximum likelihood

estimator described by Arellano (2003), pp. 68-69, in a multiple imputation routine. The figure also shows related results by Cocco et al. (2005), p. 500 .

\begin{tabular}{|c|c|c|c|c|c|c|c|c|c|c|}
\hline & & \multicolumn{3}{|c|}{ Higher Education } & \multicolumn{3}{|c|}{ Secondary Education } & \multicolumn{3}{|c|}{ Elementary Education } \\
\hline & & $\begin{array}{c}\text { ML } \\
\text { Estimate }\end{array}$ & $\begin{array}{c}\text { Asympt. } \\
\text { SE }\end{array}$ & t-ratio & $\begin{array}{c}\text { ML } \\
\text { Estimate }\end{array}$ & $\begin{array}{l}\text { Asympt. } \\
\text { SE }\end{array}$ & t-ratio & $\begin{array}{c}\text { ML } \\
\text { Estimate }\end{array}$ & $\begin{array}{l}\text { Asympt. } \\
\text { SE }\end{array}$ & t-ratio \\
\hline & & \multicolumn{9}{|c|}{ Baseline case } \\
\hline Male & $\begin{array}{l}\text { perm } \\
\text { trans } \\
\mathrm{N}\end{array}$ & $\begin{array}{r}0.03802 \\
0.08258 \\
1,470\end{array}$ & $\begin{array}{l}0.00636 \\
0.00439\end{array}$ & $\begin{array}{c}5.98211 \\
18.82270\end{array}$ & $\begin{array}{r}0.00872 \\
0.07678 \\
9,290\end{array}$ & $\begin{array}{l}0.00119 \\
0.00133\end{array}$ & $\begin{array}{r}7.29940 \\
57.72872\end{array}$ & $\begin{array}{l}0.04066 \\
0.05172 \\
1,142\end{array}$ & $\begin{array}{l}0.00549 \\
0.00381\end{array}$ & $\begin{array}{r}7.40985 \\
13.56224\end{array}$ \\
\hline Female & $\begin{array}{l}\text { perm } \\
\text { trans } \\
\mathrm{N}\end{array}$ & $\begin{array}{l}0.06624 \\
0.08525 \\
787\end{array}$ & $\begin{array}{l}0.01003 \\
0.00639\end{array}$ & $\begin{array}{c}6.60173 \\
13.34808\end{array}$ & $\begin{array}{r}0.04437 \\
0.13363 \\
7,626\end{array}$ & $\begin{array}{l}0.00289 \\
0.00275\end{array}$ & $\begin{array}{l}15.33544 \\
48.66876\end{array}$ & $\begin{array}{r}0.05677 \\
0.13542 \\
1,786\end{array}$ & $\begin{array}{l}0.00718 \\
0.00609\end{array}$ & $\begin{array}{c}7.91047 \\
22.22520\end{array}$ \\
\hline & & \multicolumn{9}{|c|}{ Employees only } \\
\hline Male & $\begin{array}{l}\text { perm } \\
\text { trans } \\
\mathrm{N}\end{array}$ & $\begin{array}{r}0.02386 \\
0.07991 \\
1,224\end{array}$ & $\begin{array}{l}0.00488 \\
0.00406\end{array}$ & $\begin{array}{r}4.89061 \\
19.69859\end{array}$ & $\begin{array}{r}0.00851 \\
0.05728 \\
7,973\end{array}$ & $\begin{array}{l}0.00087 \\
0.00086\end{array}$ & $\begin{array}{r}9.80450 \\
66.28745\end{array}$ & $\begin{array}{r}0.03260 \\
0.04145 \\
1,019\end{array}$ & $\begin{array}{l}0.00554 \\
0.00373\end{array}$ & $\begin{array}{r}5.87912 \\
11.12412\end{array}$ \\
\hline Female & $\begin{array}{l}\text { perm } \\
\text { trans } \\
\mathrm{N}\end{array}$ & $\begin{array}{l}0.08046 \\
0.05021 \\
706\end{array}$ & $\begin{array}{l}0.01066 \\
0.00608\end{array}$ & $\begin{array}{l}7.54674 \\
8.26056\end{array}$ & $\begin{array}{r}0.03811 \\
0.11859 \\
7,032\end{array}$ & $\begin{array}{l}0.00266 \\
0.00228\end{array}$ & $\begin{array}{l}14.34251 \\
52.04371\end{array}$ & $\begin{array}{r}0.05059 \\
0.12569 \\
1,689\end{array}$ & $\begin{array}{l}0.00757 \\
0.00586\end{array}$ & $\begin{array}{r}6.68778 \\
21.43655\end{array}$ \\
\hline
\end{tabular}


Table 3 (continued) 
Table 4: Permanent and Transitory Labor Income Shocks, Full-time Workers Only

This figure shows results from estimating $\sigma_{\varepsilon}^{2}$ and $\sigma_{u}^{2}$ for full-time workers only using the maximum likelihood estimator described by Arellano (2003), pp. 68-69, in a multiple imputation routine.

\begin{tabular}{|c|c|c|c|c|c|c|c|c|c|c|}
\hline & & \multicolumn{3}{|c|}{ Higher Education } & \multicolumn{3}{|c|}{ Secondary Education } & \multicolumn{3}{|c|}{ Elementary Education } \\
\hline & & $\begin{array}{c}\text { ML } \\
\text { Estimate }\end{array}$ & $\begin{array}{c}\text { Asympt. } \\
\text { SE }\end{array}$ & t-ratio & ML Estimate & ympt. SE & t-ratio & ML Estimate & ympt. SE & t-ratio \\
\hline & & \multicolumn{9}{|c|}{ Baseline case } \\
\hline Male & $\begin{array}{l}\text { perm } \\
\text { trans } \\
\mathrm{N}\end{array}$ & $\begin{array}{r}0.02302 \\
0.07116 \\
1,236\end{array}$ & $\begin{array}{l}0.00480 \\
0.00410\end{array}$ & $\begin{array}{r}4.79597 \\
17.35969\end{array}$ & $\begin{array}{r}0.00392 \\
0.06443 \\
8,696\end{array}$ & $\begin{array}{l}0.00090 \\
0.00102\end{array}$ & $\begin{array}{r}4.33447 \\
63.38550\end{array}$ & $\begin{array}{r}0.02315 \\
0.04805 \\
1,063\end{array}$ & $\begin{array}{l}0.00422 \\
0.00244\end{array}$ & $\begin{array}{r}5.49095 \\
19.66205\end{array}$ \\
\hline \multirow[t]{2}{*}{ Female } & $\begin{array}{l}\text { perm } \\
\text { trans } \\
\mathrm{N}\end{array}$ & $\begin{array}{l}0.04228 \\
0.06501 \\
360\end{array}$ & $\begin{array}{l}0.01077 \\
0.00966\end{array}$ & $\begin{array}{l}3.92449 \\
6.73188\end{array}$ & $\begin{array}{r}0.00298 \\
0.05220 \\
3,485\end{array}$ & $\begin{array}{l}0.00160 \\
0.00146\end{array}$ & $\begin{array}{r}1.86665 \\
35.77055\end{array}$ & $\begin{array}{l}0.00283 \\
0.05204 \\
737\end{array}$ & $\begin{array}{l}0.00263 \\
0.00316\end{array}$ & $\begin{array}{r}1.07460 \\
16.46652\end{array}$ \\
\hline & & \multicolumn{9}{|c|}{ Employees only } \\
\hline Male & $\begin{array}{l}\text { perm } \\
\text { trans } \\
\mathrm{N}\end{array}$ & $\begin{array}{r}0.00918 \\
0.06672 \\
1,020\end{array}$ & $\begin{array}{l}0.00273 \\
0.00281\end{array}$ & $\begin{array}{r}3.35815 \\
23.73876\end{array}$ & $\begin{array}{l}0.00426 \\
0.04337 \\
7,465\end{array}$ & $\begin{array}{l}0.00072 \\
0.00072\end{array}$ & $\begin{array}{r}5.92675 \\
60.15801\end{array}$ & $\begin{array}{r}0.02673 \\
0.03201 \\
949\end{array}$ & $\begin{array}{l}0.00427 \\
0.00296\end{array}$ & $\begin{array}{r}6.26045 \\
10.82668\end{array}$ \\
\hline Female & $\begin{array}{l}\text { perm } \\
\text { trans } \\
\mathrm{N}\end{array}$ & $\begin{array}{r}0.05408 \\
0.04610 \\
323\end{array}$ & $\begin{array}{l}0.01113 \\
0.00657\end{array}$ & $\begin{array}{l}4.85895 \\
7.02191\end{array}$ & $\begin{array}{r}0.00042 \\
0.04571 \\
3,259\end{array}$ & $\begin{array}{l}0.00078 \\
0.00108\end{array}$ & $\begin{array}{r}0.53686 \\
42.14144\end{array}$ & $\begin{array}{r}0.00354 \\
0.04928 \\
695\end{array}$ & $\begin{array}{l}0.00331 \\
0.00308\end{array}$ & $\begin{array}{r}1.06834 \\
15.99591\end{array}$ \\
\hline
\end{tabular}


Table 4 (continued) 


\section{Implications for Portfolio Choice}

In this section we analyse the results from solving and simulating the model of Cocco et al. $(2005)^{38}$ for different types of Swiss investors. For this purpose, we first show how the previous section's empirical results can be used to stylize different types of investors. The most notable distinction is that between individual investors and couples as investors. Baseline portfolio results are then analysed in two subsections corresponding to individual investors and couples as investors, respectively. A scenario analysis of replacement rates and realistic correlations between labor income and equity returns concludes the section. ${ }^{39}$

\subsection{A Stylized Typology of Swiss Investors}

We now ask which Swiss investor types we shall distinguish and how we shall stylize them in the portfolio analysis, given the previously found empirical patterns. This is a nontrivial question due to the design of the data at hand: in the SLFS survey, only one member of any given household (the so called target respondent) is questioned. The respondent reports (if at all) her individual labor income and total household income. Total household income must be discarded as it includes capital income which is endogenous in a study of asset allocation as the present one. This implies that from SLFS data, one can directly estimate only individual age-earnings profiles and earnings variances, but not those of couples or households.

Individual earnings data naturally lends itself to the calibration of a portfolio choice model for an individual or single investor. We depict individual investors as follows: in the case of men part-time employment is not a significant empiri$\mathrm{cal}$ phenomenon. We thus combine the age-earnings profiles estimated from the fully employed male education groups (section 3.4.1, Figure 2) with the variance estimates obtained for the same groups (section 3.4.2, Table 4) to obtain a reasonably close approximation to the labor income dynamics of a representative man belonging to either group.

The case is different for women: many women work part-time from about their thirties on, while a substantial fraction of women remains fully employed throughout life. ${ }^{40}$ We thus suggest to reflect this difference in the portfolio analysis by stylizing either type of female investor using appropriately combined

38 See section 2 above.

39 We are grateful to an anonymous referee for suggesting these analyses.

40 See section 3.3 above. 
Figure 3: Overview of Examined Swiss Investor Types

This figure shows all stylized investor types considered in the portfolio choice analysis.

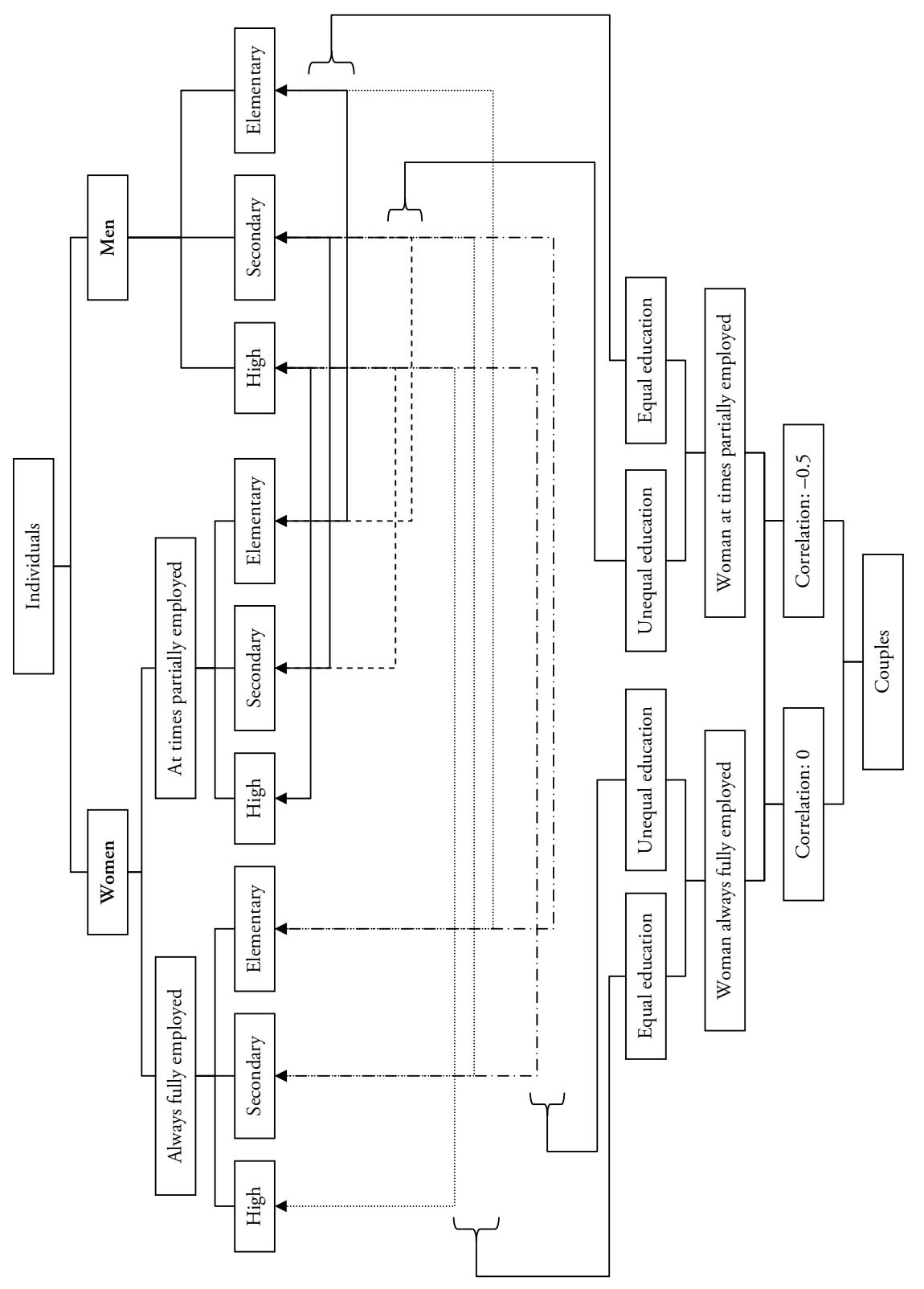


age-earnings profiles and variance estimates. Specifically, we consider the profiles and variance estimates derived from the fully employed female samples as representative of the latter case. For the former case, we view the profiles estimated from the joint sample of fully and partially employed women as approximately representative of a female investor who decreases labor supply during her thirties to fourties. ${ }^{41}$ For the variances in this case, we also use the estimates obtained from the joint samples, despite the fact that they might be overstated due to the higher income variability imported into these samples by the inclusion of fulltime workers with higher earnings. We view the higher variances as to reflect the higher ex-ante income variance of women who are facing pregnancy and parenting at an uncertain point-in-time. ${ }^{42}$

Our implicit assumption thereby is that the labor supply reduction of women goes hand in hand with pregnancy and parenting. This assumption is justified by tentative evidence in our data: in the highly educated female group only $23 \%$ of all fully employed women have at least one child present in their household, while this is true for $59 \%$ of all partially employed women. This situation is almost identical in the secondary education group. In the elementary education group, the fraction of fully employed women with at least one child is somewhat higher with 38\%, whereas the corresponding fraction of partially employed women is slightly lower with $52 \%{ }^{43}$

Now, one might rightfully question the empirical relevance of single investors. As we have just seen, in the majority of cases, partially employed women have at least one child and it would appear likely that they have reduced their labor supply due to this fact in the first place and further that their pregnancy and parenting are associated with a family design featuring an additional income earner. This would suggest that their investment decisions are taken on the household level, instead of on the individual level. We can tentatively explore

41 One would optimally estimate profiles for various amounts of 'labor supply reduction' on corresponding sub-samples of women in this case. This could potentially be accomplished using SLFS variable "ek03". However, sample sizes would then become unreliably small.

42 The alternative to estimate the variances from sub-samples of female part-time workers only is problematic: while the estimation would not be difficult, we would have to use both the 'part-time' and the 'full-time' variance in the model solution: this is complicated as the exact period of reduced labor supply would have to be constituted arbitrarily.

43 These figures were obtained by exploring in detail the age structure of all household members of those respondents that belong to the final sample used in the empirical analysis. We use age differences bigger than +15 years between the respondent and other household members as a proxy for the presence of children. The 15 year threshold delivers a good separation, but is, of course, not entirely free of error. 
the relative importance of single vs. household investors using our data: ${ }^{44}$ in the female case, observations from single investors account for $42 \%, 40 \%$ and $35 \%$ of all observations in the high, secondary and elementary education subgroups, respectively. In the male case, the corresponding figures amount to $31 \%, 31 \%$ and $28 \%$. Further, of all observations from highly educated, fully employed women $27 \%$ belong to single investors. And while, with $15 \%$, there are less single investors in the highly educated partially employed female sample, their weight is still sizable. This relative importance of single investors is almost identical in the remaining female education groups.

Despite the just established significance of single investors, a majority of observations in all female and male education groups are from respondents that are most likely household investors. This makes the consideration of household portfolio choice in addition to that of singles, necessary. Given that household income dynamics cannot be directly estimated from the data as described above, we combine individual profiles and variances as follows: we assume that both partners are equally-aged and sum up earnings at each point in time. Similarly, the individual partners' transitory and permanent variances are combined using appropriate correlation assumptions. Unfortunately, the same reason that prevents us from estimating couples' earnings profiles and variances directly, also prevents us from calibrating their earnings correlations empirically: earnings data is only available for one member of a given household. We thus analyse the two plausible scenarios of independence and mutual correlation of -0.5 .

Figure 3 is an overview of all investor types considered in this section's portfolio choice analysis. We consider nine types of individual investors distinguished by gender, education and - in the female case - activity rate. Additionally, we consider twenty types of couples distinguished by the female partner's activity rate, by whether the partners are equally educated or not and by whether the partners' earnings shocks are negatively correlated or noncorrelated.

44 We isolate observations from households where the respondent is nonmarried and either the only adult or lives with her parents vs. observations from married respondents and from households where in addition to the respondent there is one and only one individual of similar age (the partner) with all other household members likely to be children. 


\subsection{Baseline Results}

\subsubsection{Individuals as Investors}

Figure 4 shows mean forward simulated equity shares as a function of age for men (panel A), partially vs. fully employed women (panel B), men vs. partially employed women (panel C) and men vs. fully employed women (panel D).

Consider panel A: men's forward simulated equity shares are $\mathrm{V}$-shaped in age, which is characteristic of basic life cycle models with power utility (i.). ${ }^{45}$ Highly educated men have riskier portfolios than men with elementary education during the larger part of working life, but this difference is declining in age and shortly before retirement, there exists an intersection where the portfolios of highly educated men become more conservative than those of men with elementary education (ii.). Men with secondary education invest substantially more aggressively than their contemporaries with elementary or higher education, particularly during working life (iii.).

Now consider partially employed womens' equity shares in panel B: despite the fact that effect ii. is present in a similar form here, too, these women's investment behavior is approximately independent of education (iv.). Contrary to the male case, equity holdings remain roughly constant during retirement, such that the profile shape appears more as a mirror-inverted lying L than a V (v.). Fullyemployed women with high education invest similarly as partially-employed women with high education (vi.), whereas fully-employed women with elementary and secondary education invest coincidingly (vii.), but far more aggressively than all other women (viii.). Effect ii. is not present in the fully-employed female group. These findings for women can be expressed equivalently in terms of the activity rate: women with high education invest similarly independent of their activity rate. Women with elementary or secondary education invest significantly differently depending on whether they are partially or fully employed.

In summary, we do not find a strong education specific investment pattern which is independent of gender. Rather, education specific investment advice depends on gender and - in the female case - on activity rate.

45 However, power utility alone is not sufficient for this general finding. See Wallmeier and ZaINHOFER (2006) for a review of life cycle models with power utility that imply different age-equity patterns.

46 All of these observations can identically be made when median instead of mean forward simulated age-equity profiles are considered. 
Panel C illustrates that partially employed women invest substantially more conservatively than men throughout life (ix.). In panel D we observe that the investment behavior of fully-employed women with secondary or elementary education, though slightly more conservative, resembles that of men with secondary education (x.). ${ }^{46}$

We now explore the economic forces that determine these results. For technical reasons unrelated to our present interest, the policy function for the equity share is derived as a function of the cash-on-hand-to-permanent-income ratio (henceforth $C t P I)$. A general feature of this policy function is that a higher $C t P I$ implies a lower equity share (ceteris paribus). ${ }^{47} \mathrm{~A}$ key to understanding the observed allocation differences is thus to understand the differences in CtPI evolution, which in turn can be understood by analysing the investor's savings behavior. The investor saves for two reasons: to smooth the consumption path in face of the income drop experienced at the beginning of retirement and to buffer adverse income shocks. The strength of the retirement savings motive is determined by the shape of the earnings profile and the replacement rate, ${ }^{48}$ whereas the strength of the buffer stock savings motive is determined by the size of the income variances. Dissaving during retirement is driven mainly by the mortality probability. Differences in these factors account for differences in savings and thus wealth evolution which - relative to earnings - determines the observed allocation differences between investors.

To see this in more detail, the left hand column of Figure 5 plots median forward simulated life cycle labor income together with consumption as functions of age for men (panel A), partially employed women (panel C) and fully employed women (panel E); the right hand column exhibits corresponding forward simulated savings relative to labor income for the first thirty periods of working life. Figure 6 plots median forward simulated CtPI as a function of age.

High education graduates are assumed to start working life five years later than investors with lower education. By that time, the latter have already accumulated some wealth, while the former are just starting to save from scratch. Additionally, high education graduates usually experience higher permanent income growth than less educated investors in the beginning of working life. Their CtPI is thus

47 The present value of future labor income corresponds to an implicit riskless asset holding. The higher is thus cash-on-hand, the weaker is the implicit riskless position in entire wealth and the more conservative the investor must invest her financial wealth.

48 The elasticity of intertemporal substitution (inverse of the coefficient of relative risk aversion in the case of power utility) was assumed identical for all investor types. 
Figure 4: Equity Holdings, Individuals
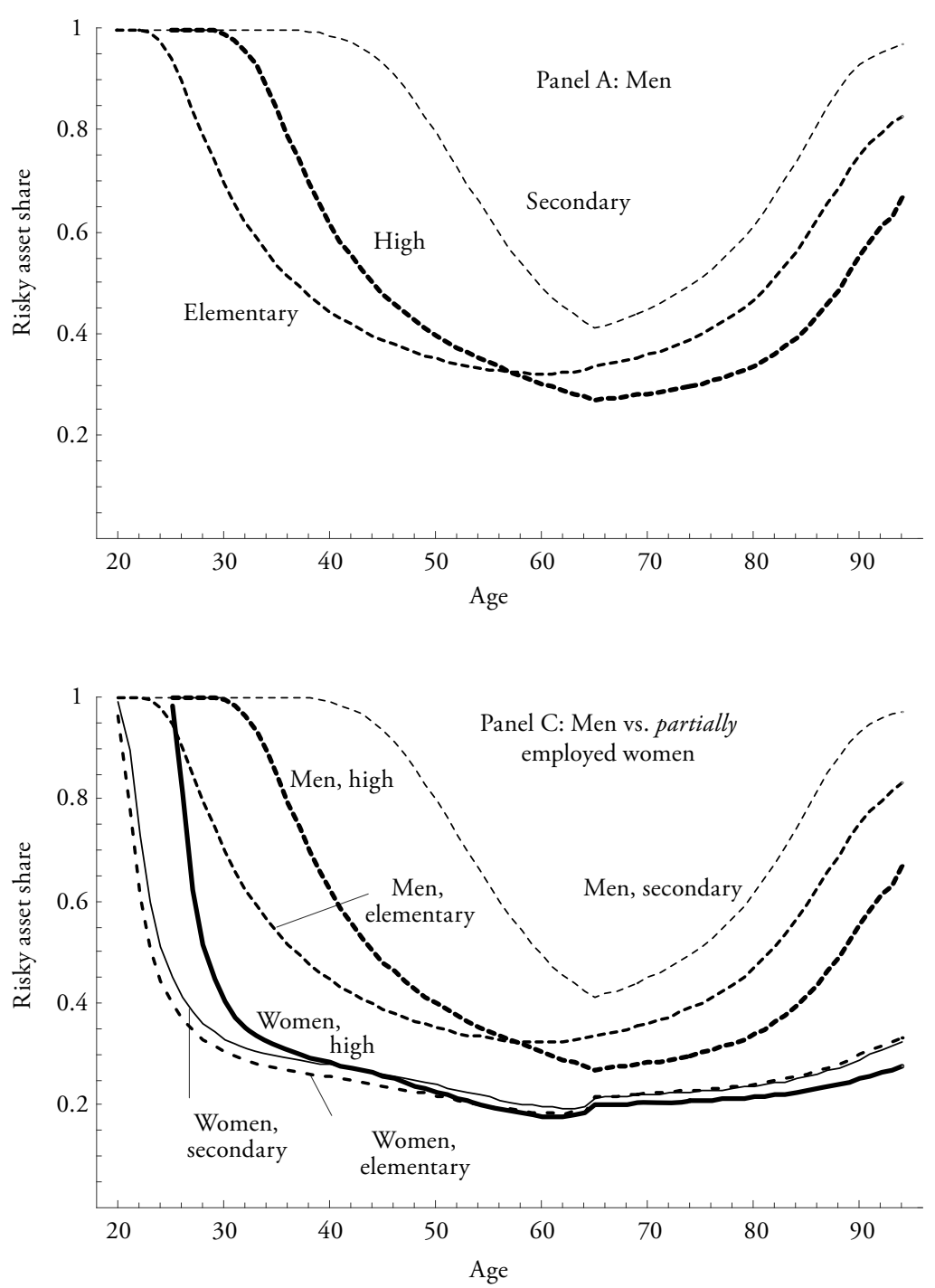
Figure 4 (continued)
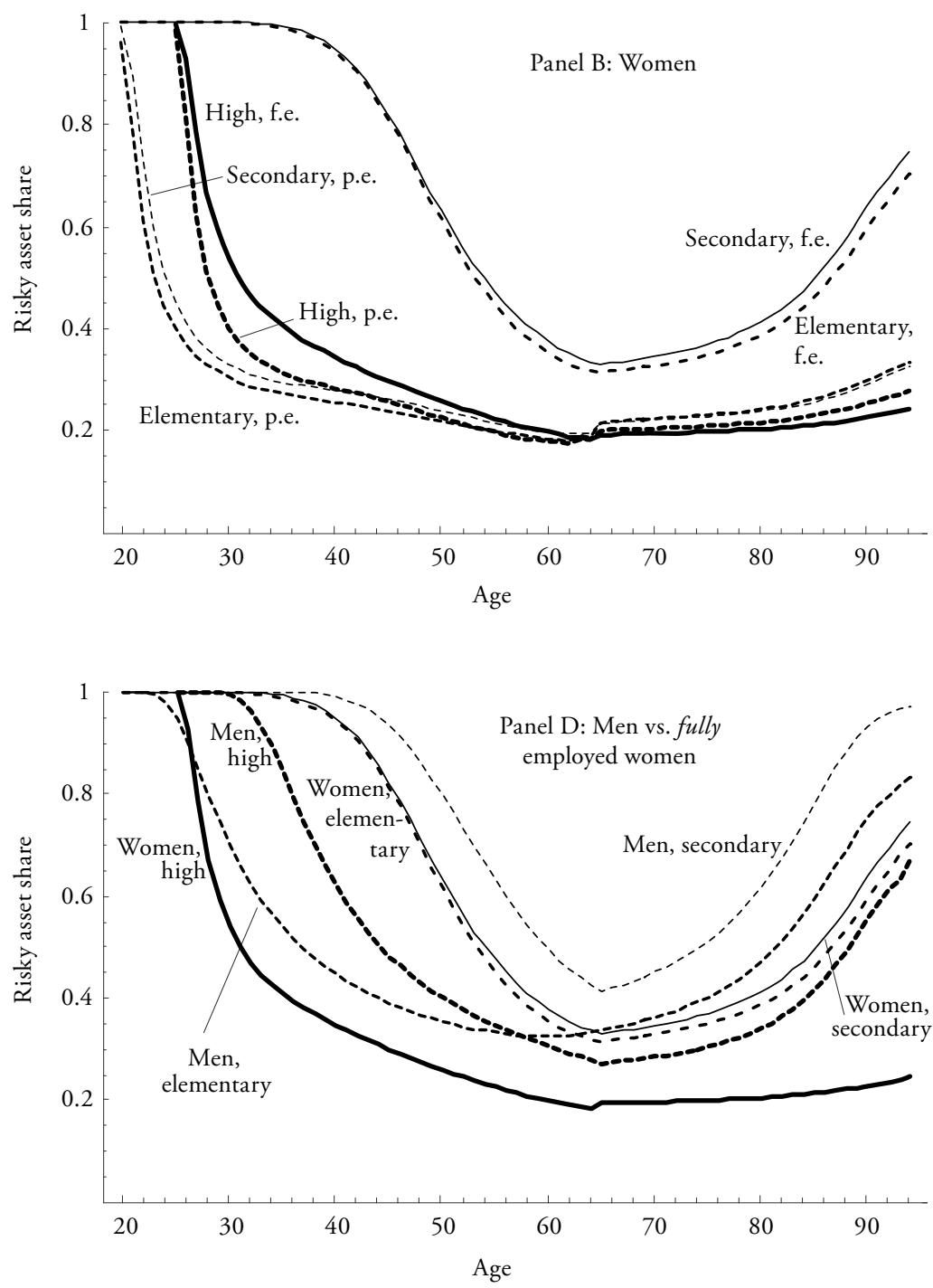

This figure shows mean forward simulated equity holdings as a function of age for individual investors. The abbreviations "p.e." and "f.e." denote female investors who are temporarily partially employed and constantly fully employed, respectively. 
Figure 5: Income, Consumption and Savings, Individuals
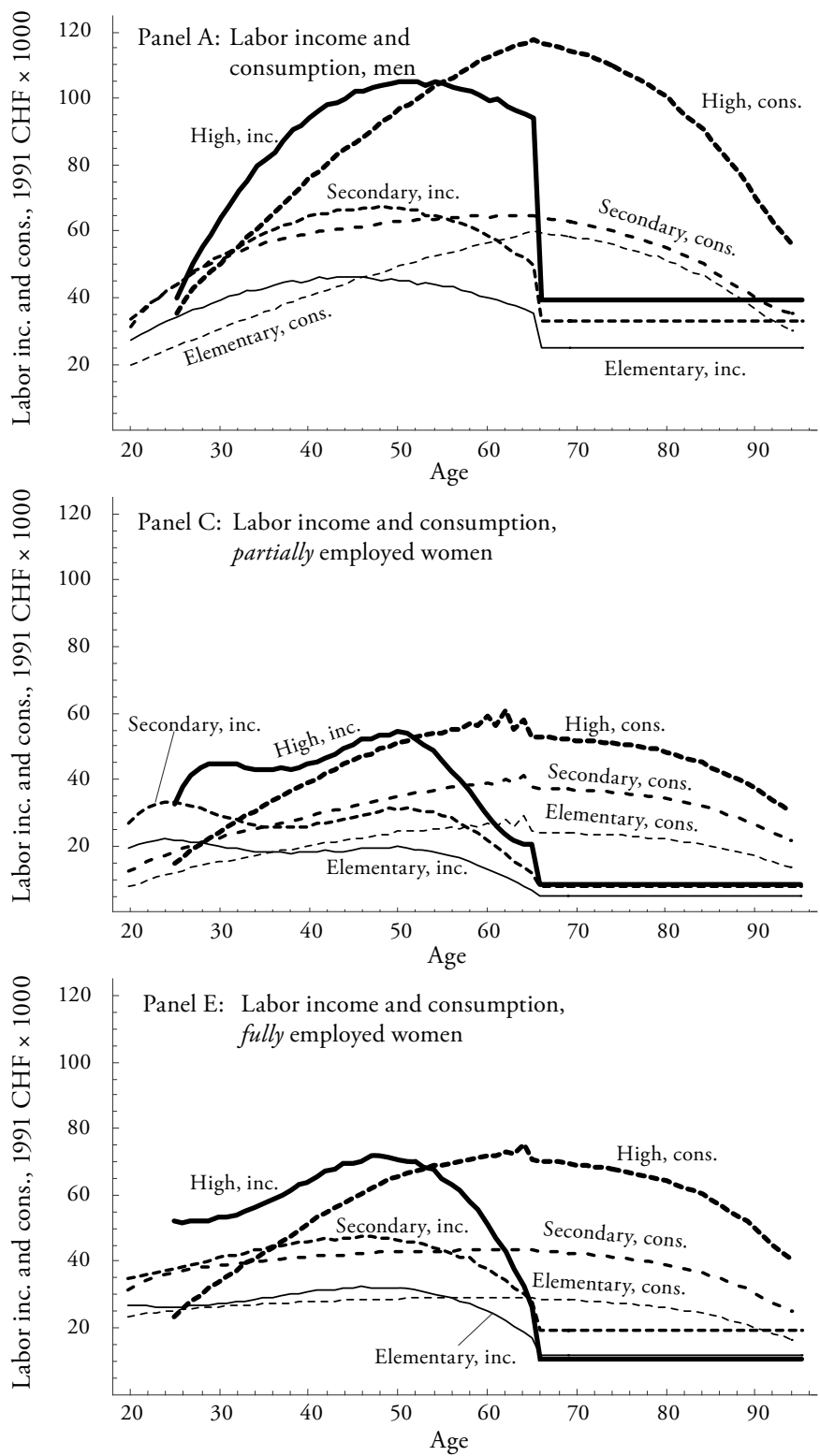
Figure 5 (continued)
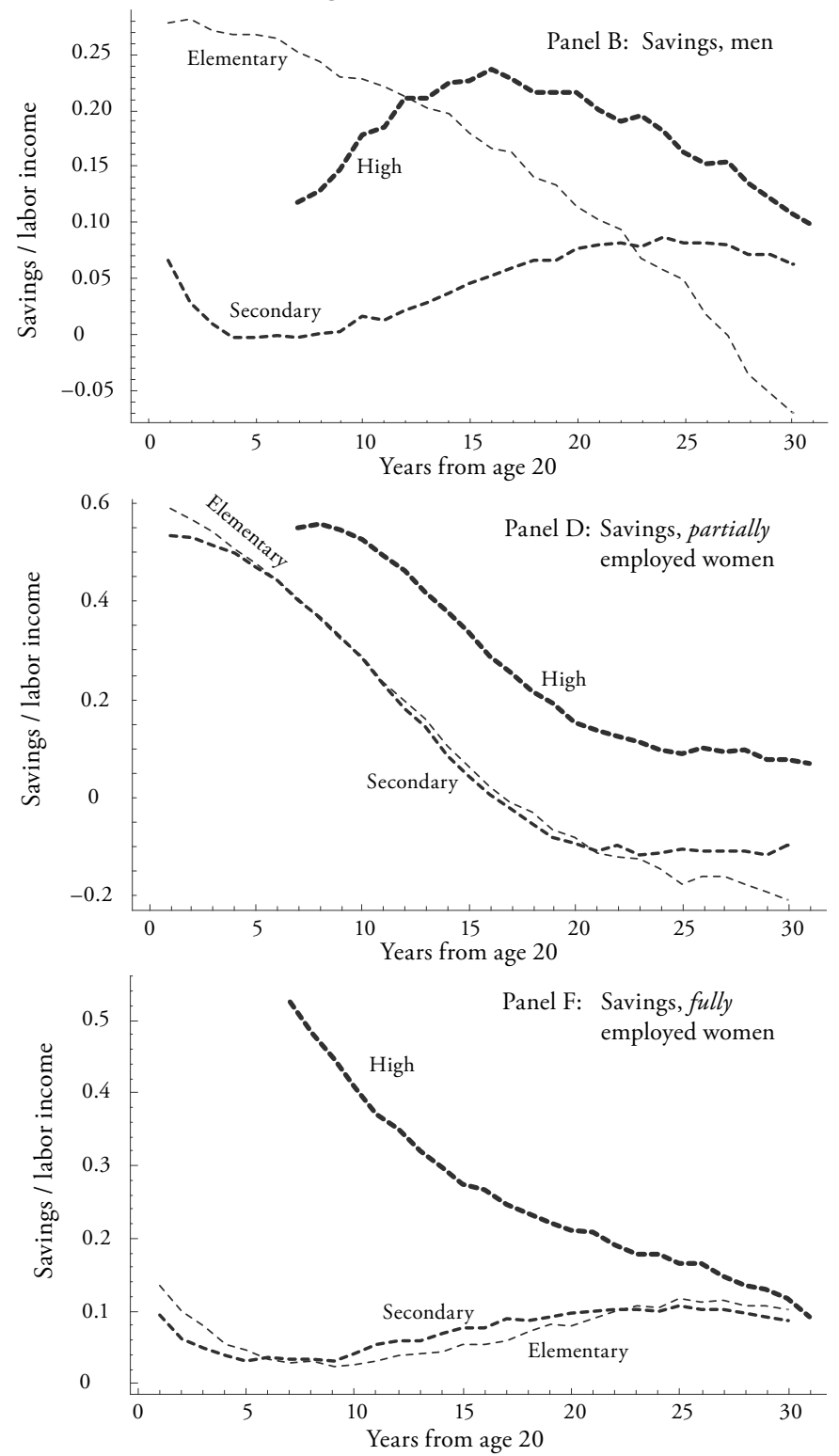

This figure shows median forward simulated labor income and consumption in $1991 \mathrm{CHF}$ as functions of age. It also exhibits median forward simulated savings over labor income as a function of the first thirty periods of life. 
lower during this period, implying a higher equity share (we call this the 'startingage-gap'). Due to a lower replacement rate, however, highly educated investors generally need to save more for retirement than their less educated contemporaries during later working life. This means that their wealth quickly catches up with and eventually overtakes that of less educated investors. For given permanent income, this further implies that highly educated investors' equity shares converge from above to those of less educated investors and eventually become more conservative (ii.). However, as equity holdings are determined by the ratio of CtPI (not by absolute wealth holdings alone), the speed of this convergence is also influenced by the rate of permanent income growth: the higher it is, the slower is convergence and the later occurs the intersection.

In the male case, the 'starting-age-gap' is only observed between investors with high and elementary education because men with secondary education have an approximately zero permanent and a moderate transitory income variance (Table 4) and thus need to maintain no buffer stock. Consequently, they do not start to save until saving for retirement becomes an issue (Figure 5, panel B). This behavior results in a convex CtPI path, at all times substantially below those of other male investors (Figure 6, panel A) which in turn implies the observed aggressive investment (iii.). Analogous reasoning explains the investment profiles of fullyemployed women with secondary and elementary education (vii., x.) and the fact that the 'starting-age-gap' is not observed in the fully-employed female group.

Savings behavior of partially employed women differs significantly from that of either fully-employed women or men: they have a pronounced trough in their earnings profiles. Thus, in addition to the income drop at retirement, they wish to 'smooth out' this trough. This requires substantial savings early in life which are then reduced quickly as the income trough nears (Figure 5, panel D). Together, the high savings and the reduced permanent income implied by the trough, yield high CtPI ratios (Figure 6, panel B) and consequently more conservative equity holdings than men (ix.) and fully-employed women with secondary and elementary education (viii.).

Partially employed women with elementary and secondary education save congruently (Figure 5, panel D) despite different permanent variances (Table 3): contrary to highly educated women, they never recover from their income trough, which forces them to start dissaving already in their mid-thirties to maintain a smooth consumption profile (Figure 5, panels $\mathrm{C}$ and D). This results in a particularly strong 'trough-smoothing savings motive' that 'overrides' differences in desired buffer stock savings. A consequence of the identical savings behavior and the parallel income profiles is that their CtPI profiles roughly coincide throughout life, which implies identical portfolio choice (iv). 
Figure 6: Cash-to-permanent Income Ratio Individuals
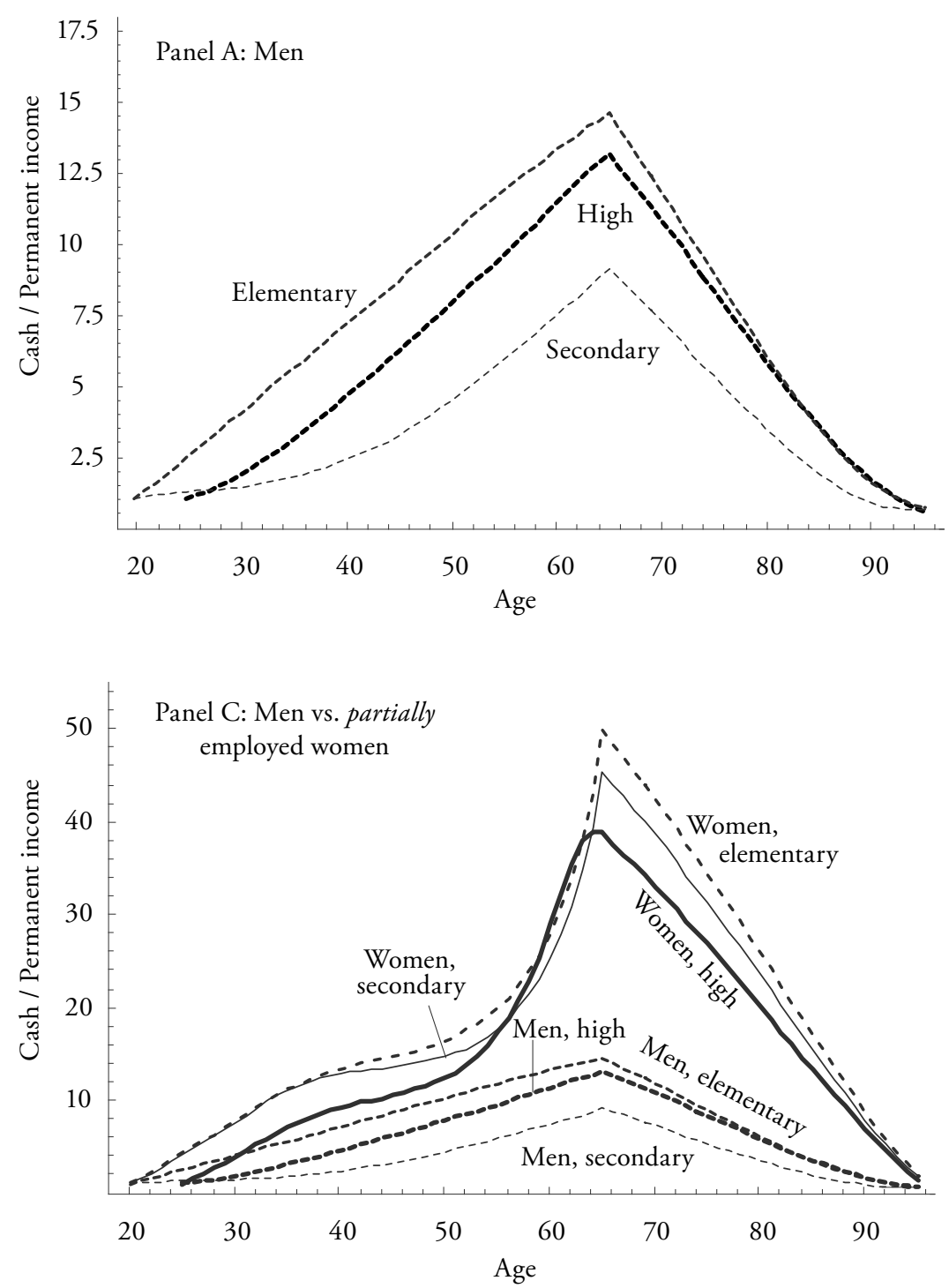
Figure 6 (continued)
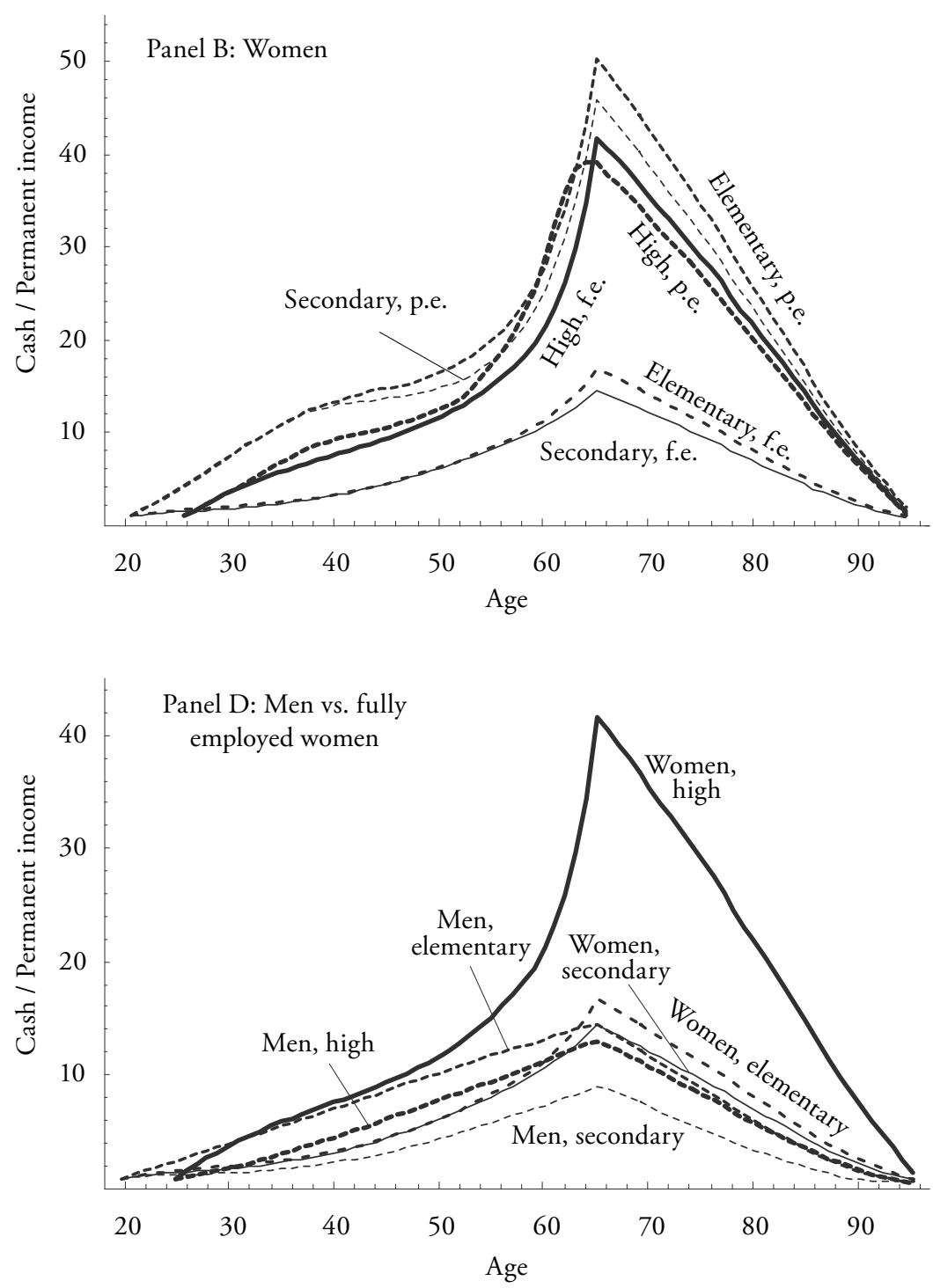

This figure shows median forward simulated cash to permanent income ratios as a function of age for individual investors. 
Partially employed women with high education are not required to dissave early because their earnings profile exhibits growth following the parenting-trough (Figure 5, panel C). This reduces the trough's impact as compared to partially employed women with lower education. The earnings profiles of partially and fully-employed women with high education are thus economically roughly equivalent, despite their different shapes. Because their permanent variances are also similar, savings and investment behavior is approximately independent of activity rate in the female high education group (vi.).

During retirement, an important additional factor comes into play: beginning with about age 60 , males' conditional survival probabilities are increasingly lower than those of identically aged females. Since a low conditional survival probability effectively translates into a lower discount factor, men are more impatient than women at advanced ages. Thus, they reduce their wealth more quickly than women during retirement, ${ }^{49}$ which leads to increasing equity allocations accounting for the observed V-shape of the male equity profiles (i.). The slower wealth reductions of the more patient women entail constant equity holdings during retirement and thus the observed mirror-inverted lying L-shaped profiles (v.).

\subsubsection{Couples as Investors}

Figure 7 now reports equity allocation profiles of couples. We are interested in the effects of negatively correlated income shocks of the two partners, the effects of the two partners belonging to different education groups (Figure 7, first line vs. second line) and the effects of the female partner reducing her labor supply during her thirties in favour of assuming a parenting role (Figure 7, left-hand column) vs. remaining fully employed at all times (Figure 7, right-hand column).

The main findings are outlined as follows: if the woman in a partnership expects an income trough e.g. as a reaction to a parenting role (call this design A), then the couple's optimal portfolio choice is effectively the same, independent of both partners' education. ${ }^{50}$ If the woman in a partnership expects to be fully

49 This is visible in the wealth profiles which are not reported for brevity. During retirement, income is no longer risky but constant. Thus, retirement income is permanent and the CtPI becomes identical to one plus the wealth to retirement income ratio. But since retirement income is constant over time, CtPI changes only if wealth changes and it suffices to consider the evolution of wealth across the investor groups in order to analyse portfolio choice during retirement.

50 A minor exception are the previously found 'starting-age-gaps' that are also present in the couple cases: couples with higher education invest slightly more aggressively than couples with lower education in the beginning of working life. With advancing ages, this difference gradually becomes smaller and is subsequently reversed. 
Figure 7: Equity Holdings, Couples
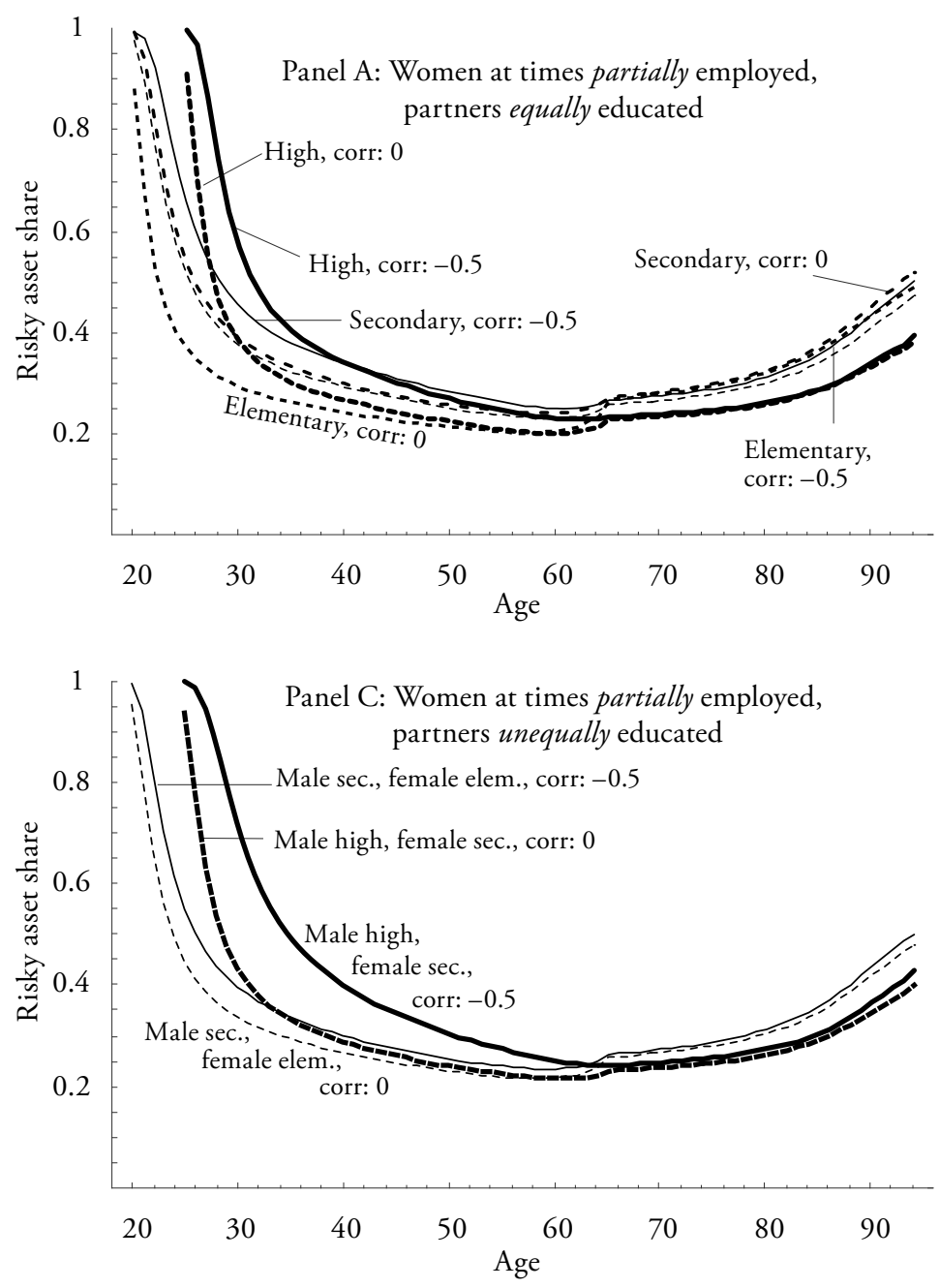
Figure 7 (continued)
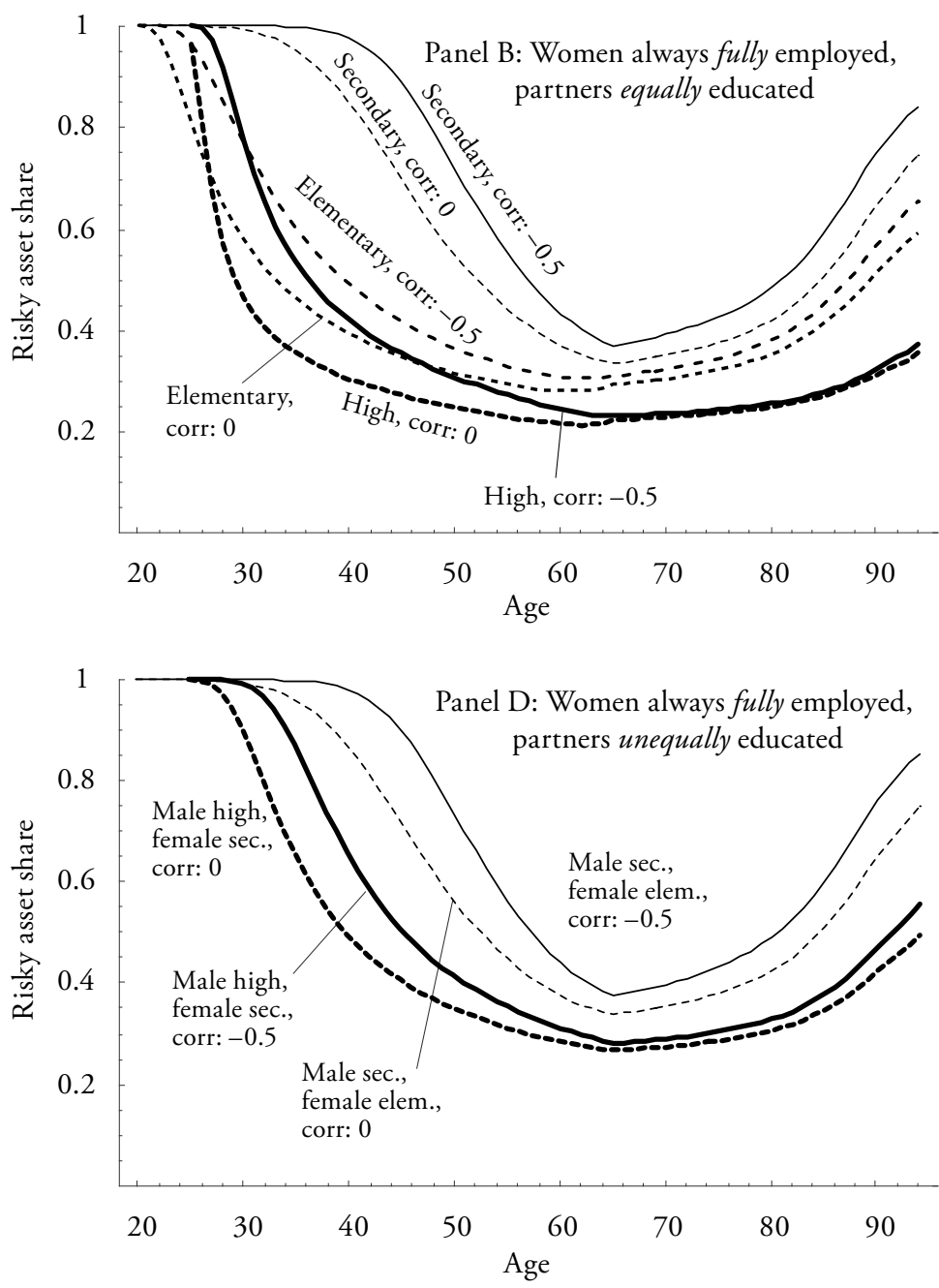

This figure shows mean forward simulated equity holdings as a function of age for couple-investors. 
employed at all times (call this design B), equity holdings are generally higher than in the previous case and are a function of education.

Specifically, the general increase in equity holdings due to design B as compared to A (allocation differences between panels A and B in Figure 7), is highest for couples where both partners are secondary education graduates, followed by couples composed of two elementary education graduates with a lower increase and then by couples consisting of two highly educated partners with a moderate increase. This finding can be confirmed from unequally educated couples (panels $\mathrm{C}$ vs. D in Figure 7) where the increase is larger for that couple where the male partner has secondary education.

Within the group of design-B-couples (Figure 7, right-hand column), equity investments differ as a function of education: couples where both partners have a secondary education, e.g., invest significantly more in equity than couples where both partners have either an elementary or a higher education (Figure 7, panel B). The same finding applies to couples with unequally educated partners (Figure 7, panel D): we find that couples with higher education (male-high / female-secondary education) have substantially lower equity holdings than couples with less education (male-secondary / female-elementary education) starting with about age 30 . We can thus conclude that - under design $\mathrm{B}$ - couples where at least the male partner has a secondary education invest more in equity throughout life than other couple types.

Independent of the couple's design (A or B), a negative earnings-shock-correlation of -0.5 permits couples to invest more aggressively during working life (Figure 7, all panels). However, the effect is weak as compared to the previously described implications of the couple's labor supply scheme (design A vs. B) and the distribution of education across the partners.

The effect of the negative correlation is easily explained: the couple's combined earnings-shock-variances are lower with correlation present than without. ${ }^{51}$ This implies that required buffer stocks are lower and less wealth is accumulated. For given permanent income, CtPI accumulation is thus also lower and equity holdings are therefore higher. Intuitively, correlated income streams make the couple's combined income stream less risky and more bond-like. Expected future labor income thus makes up a larger fraction of the couple's entire wealth and permits more aggressive investment of financial wealth.

The other observations can be explained mainly by differences in permanent variances between the couples: permanent variances are more uniformly

51 More specifically, for a correlation of -0.5 , the couple's variances are reduced by the product of the two partners' individual standard deviations. 
distributed in the group of couples with temporarily partially employed women as compared to the group of couples with continuously fully employed women where they exhibit a higher variability. Additionally, permanent variances are substantially lower in the latter group than in the former. ${ }^{52}$

\subsection{Additional Scenario Analyses}

\subsubsection{Replacement Rates}

The baseline parameter settings included $O E C D$ point estimates for replacement rates from mandatory Swiss old-age provision schemes. ${ }^{53}$ In Switzerland, mandatory old-age provision is organised in two pillars, a pay-as-you-go financed, redistributive system called $A H V$ and a funded occupational scheme named $B V G{ }^{54}$ Both of these schemes are currently facing significant challenges that might well impact future replacement rates. We shall thus briefly examine these challenges and assess their potential implications on replacement rates and life-cycle portfolio choice of Swiss investors, using several distinctive scenarios.

A prominent general risk factor is the uncertain demographic evolution and its economic consequences. Several studies commissioned by the Swiss Federal Office for Social Insurance (BSV) have investigated this issue by using FOS population projections in different macroeconomic forecasting models. ${ }^{55}$ They conclude that a scenario assuming low fertility and migration, but high life expectancy at birth, ${ }^{56}$ represents the most formidable threat to the $A H V$ and that it would require substantial sales tax increases in the near future to alleviate this threat. ${ }^{57}$ We thus consider a scenario where these sales tax increases are unfeasible and $A H V$ benefits must be reduced without compensation, decreasing the overall replacement rate from both mandatory pillars by $50 \%$ for elementary education graduates, $40 \%$ for secondary education graduates and $35 \%$ for high education graduates. ${ }^{58}$

52 An exception are couples with two highly educated partners where the variance is only slightly lower.

53 See section 2 above.

54 See e.g. Queisser and Vittas (2000) or Sousa-Poza and Van Dam (2002) for further information on the Swiss old-age provision system.

55 See Müller et al. (2003), Schluep (2003), Abrahamsen and Hartwig (2003) and IDA (2003).

56 FOS scenario D-00-2000 ('increased ageing').

57 See IDA (2003).

58 Overall replacement rates are affected asymmetrically because the first two pillars are integrated by the concept of coordinated earnings: Low income earners receive a higher replacement 


\section{Table 5: Replacement Rates}

This table shows replacement rates for the baseline case and three alternative scenarios. The replacement rates in the alternative scenarios are obtained by reducing the appropriate baseline replacement rates using the reduction factors derived in this section's main text.

\begin{tabular}{lccc}
\hline & & $\begin{array}{c}\text { Education } \\
\text { Secondary }\end{array}$ & High \\
\hline Female & Elementary & Ser & \\
Baseline & & & \\
Unfavorable demographics & 0.716 & 0.680 & 0.418 \\
First BVG revision & 0.666 & 0.408 & 0.272 \\
BVG individualization & 0.537 & 0.612 & 0.364 \\
Male & & & 0.314 \\
Baseline & 0.714 & 0.673 & \\
Unfavorable demographics & 0.357 & 0.404 & 0.414 \\
First BVG revision & 0.664 & 0.606 & 0.360 \\
BVG individualization & 0.536 & 0.505 & 0.311 \\
\hline
\end{tabular}

Recently, the $B V G$ has been revised. Among the most prominent revisions, it is expected, that the reduction of the conversion factor balances the increase of coordinated earnings on the one hand and that the increase in female retirement ages offsets the change in the age structure of their minimum old-age credits on the other hand. The first $B V G$ revision should thus not affect occupational pensions by much. We consider a scenario with very mild overall replacement rate reductions $(7 \%, 10 \%$ and $13 \%$ for elementary, secondary and high education graduates, respectively) induced by lower $B V G$ benefit levels.

A frequently debated topic for future $B V G$ revision is that of continued individualization. This debate comprises both, individualization of the asset accumulation process and a possible detachment of $B V G$ provision from the employer's pension fund (free choice of pension fund). ${ }^{59}$ First measures to individualize asset accumulation in the supra-mandatory part of the $B V G$ were included in

rate from the AHV than high income earners. A higher fraction of their overall first and second pillar pension consists of the AHV pension and they are thus more strongly affected by an AHV benefit reduction. We do not further discriminate between men and women in this analysis. The reduction rates are set arbitrarily, as empirical estimations of how overall replacement rates are affected in the various scenarios could not be obtained.

59 See e.g. Gerber (2002) for a comprehensive treatment of the latter issue. 
the revision package. ${ }^{60}$ Also, the Swiss Federal BVG Commission and the Federal Council have recently rejected a free choice of pension fund based on the study by Pittet and Pittet (2005). ${ }^{61}$ However, efforts to individualize mandatory $B V G$ old-age provision are likely to continue. ${ }^{62}$ In an individualized system, the inherent investment risk would be transferred to the worker. It is thus sometimes feared that increased individualization might affect workers asymmetrically and penalize mostly financially illiterate investors. Here, we thus picture a situation where workers entering the labor force today are contemplating the effects of a replacement rate reduction by $25 \%$ (independent of education), ${ }^{63}$ resulting from their financial illiteracy in some unkown type of individualized system. ${ }^{64}$

Table 5 summarizes the replacement rates for the baseline case and the three alternative scenarios. We now solve section 2's model for each of the nine basic sub-samples using the corresponding replacement rate in each of the three scenarios represented in Table 5 and keeping all global and other sample-specific parameters at their baseline values. ${ }^{65}$

When facing a lower replacement rate, the investor must generally increase her retirement savings to maintain a smooth consumption profile. This eventually leads to a higher $C t P I$ and more conservative equity holdings. As saving for retirement becomes prominent in advanced working life, equity profiles are similar early in life and only start to drift apart at advanced ages. Maximum differences are obtained towards the end of life. The first $B V G$ revision scenario with replacement rate reductions of $7-13 \%$ has almost negligible impacts in all samples. With replacement rate reductions of $25 \%$ and $35 \%-50 \%$, respectively, the $B V G$ individualization and unfavorable demographics scenarios render portfolio

60 For example, pension funds offering exclusively supra-mandatory $B V G$ insurance may offer a choice between various investment strategies. See art. 1e BVV2.

61 See EDI (2006).

62 See e.g. Отт et al. (2005) for a possible scenario.

63 Highly educated workers are financially more literate and thus likely to be less affected by individualization. However, their combined first and second pillar pensions depend more strongly on the $B V G$ as compared to the $A H V$ and they are thus relatively more affected by a given $B V G$ benefit reduction than less educated workers. We assume that the two effects balance.

64 It must be an unknown type of individualized system because if the exact form of individualization were known, the worker's pension would depend on her choices before retirement. Her replacement rate would then no longer be exogenous, as assumed in the model of Cocco et al. (2005). This would suggest to endogenize the additional choices implied by an individualized system and thus the replacement rate, in the model. We are contemplating this possibility in our work in progress.

65 Corresponding results are only reported qualitatively within the following. Details are available from the author upon request. 
choice in the male and non-highly educated, fully employed female samples significantly more conservatively, so that equity holdings during late retirement are reduced by up to $36 \%$ and $64 \%$, respectively, in these samples. Partially employed women and highly educated, fully employed women do not see their equity profiles affected at all by any of the scenarios, mainly because in these cases, the resulting pension spread is insignificant compared to the overall shape of the age earnings path. This implies that the consumption path does not have to be relocated by much in order to remain smooth.

\subsubsection{Correlated Labor Income- and Equity Return Shocks}

In its baseline form, the vector of innovations to stock returns and labor income, say $\boldsymbol{\delta}_{t}=\left(\zeta_{t}, \varepsilon_{t}, u_{t}\right)^{\prime}$, was assumed to be independently and identically distributed and its elements were assumed to be mutually uncorrelated. In the literature, results for the cases that $u_{t}$ and $\xi_{t}$ are mutually correlated or that the conditional distribution of $\boldsymbol{\delta}_{t}$ is serially correlated, indicate that life cycle portfolio choice may differ significantly with the exact correlation assumption. ${ }^{66}$

Table 6: Estimated Correlations

This table shows correlations between permanent labor income shocks $u_{t}$ and equity return shocks $\xi_{t}$, estimated from Swiss data as described in this section.

\begin{tabular}{lccc}
\hline & Elementary & $\begin{array}{l}\text { Education } \\
\text { Secondary }\end{array}$ & High \\
\hline Female & 0.1737 & -0.1192 & -0.3751 \\
Male & 0.1496 & -0.7056 & -0.5132 \\
\hline
\end{tabular}

Here, we shall use Swiss data to estimate the contemporaneous correlation between $u_{t}$ and $\zeta_{t}$ for our six basic subsamples: we obtain annual returns of the SMI and the Swiss three month LIBOR for the period 1991-2000 using Datastream, as proxies for the risky asset return and the riskfree rate, respectively, and estimate the correlation between excess stock returns and period specific means of the differenced residuals from the first stage regression. Table 6 reports the

66 See Wallmeier and Zainhofer (2006) for a review. 
results ${ }^{67}$ which are used to solve section 2's model for each of the nine basic subsamples, keeping all global and other sample-specific parameters at their baseline values. ${ }^{68}$

In reaction to a positive (negative) correlation, one would generally expect the investor to reduce (increase) equity holdings in order to undo the correlation's effect on financial wealth. As a direct change in the equity share also modifies the expected return on financial wealth, there will be a counterbalancing change in savings which in turn impacts the equity share indirectly. Further, as it is the covariance between $u_{t}$ and $\zeta_{t}$ that enters the investor's optimization problem, a given correlation should have a stronger (weaker) effect, the higher (lower) is the investor's permanent labor income variance.

Due to the large negative correlations, highly educated investors invest significantly more aggressively (up to more than twice the baseline share) during working life. Men and partially employed women with secondary education also invest more aggressively, but the effect is less pronounced. Due to the positive correlations, elementary education graduates in the male and partially employed female samples invest less in equity. Here, in the female case, stockholdings are crowded out almost completely, owing to the combination of the largest of all correlations with the high permanent earnings variance of partially employed women with elementary education. Interestingly, equity holdings of fully employed women with secondary and elementary education are not affected by the estimated correlation, while the profiles of their partially employed education peers are. This can be explained by the substantially lower permanent earnings variances of the former.

\section{Conclusions}

The purpose of this paper was to contribute to a normative decision framework to help financially illiterate Swiss workers make informed investment decisions. We estimated age-earnings profiles and earnings variances for various socioeconomic groups from Swiss panel data. The estimation results were then used to stylize several representative investor types in a normative model of life-cycle portfolio choice: we considered three education groups for men and women. In the female case, we further distinguished between women who remain fully

67 Due to the shortness of the time series, all results are insignificant and are only used as rough indicators of potential correlations in this section.

68 Corresponding figures are not reported, but are available from the author upon request. 
employed throughout working life and women who reduce labor supply during their thirties, e.g. as a result of parenting. In addition to these 'single' investors, we also analysed portfolio choice of couples accounting for different distributions of education and activity rate across the two partners. This is a broader array of investor types than considered previously. To our knowledge, it is also the first time that portfolio choice of temporarily partially employed women has been analysed.

The findings are summarized in figures 4 and 7. These graphs can be used as a rough guideline of how a given investor type should invest relative to the other types. Additionally, we stress the following lessons: temporary partial employment of women can have significant effects on life-cycle portfolio choice for both single and couple investors. A pronounced earnings trough during the thirties combined with a high permanent variance, both characteristic of a female investor who reduces her labor supply as a result of parenting, requires substantial savings already early in life and leads to conservative and differently shaped age-equity profiles. In those couples where the female partner is of the just mentioned type, investment differs substantially from that of couples where the female partner is constantly fully employed, independent of the exact distribution of education in the couple. Additionally, if a couple's earnings-shock variances are noticeably (mutually) negatively correlated, the couple can invest slightly more aggressively, independent of the partners' education. These findings highlight the importance of the exact family design and of the interrelation between the two partners' professions as well as their industry affiliations for life cycle portfolio choice.

Even if their earnings risk were identical, investors of the same age cannot simply be advised coinciding equity shares, e.g. using age-dependent rules-ofthumb. This is true because they can find themselves in different stages of their life-cycle despite being equally aged. For example, investors with higher education necessarily start their working lives later than investors with lower education because higher education takes longer to acquire. This can imply significant differences in the equity shares of identically aged investors.

The variance of permanent earnings innovations is a critical determinant of life cycle portfolio choice. Most investment differences between the Swiss investors considered in this study can be explained by differences in these variances, or by their interaction with other determinants.

Expected replacement rates at retirement may influence portfolio choice during advanced working life: investors with higher education generally have a steep and highly-leveled age-earnings profile. Due to the reallocative features of public retirement provision schemes, this usually implies that they expect a lower replacement rate than investors with less education, which forces them to save 
more for retirement in relative terms. These higher savings imply lower equity holdings. Our analysis revealed that replacement rate reductions, as could e.g. be associated with an unfavorable demographic development or potential revisions of the Swiss $B V G$, would require significantly higher savings in advanced working life and imply more conservative equity holdings extending far into retirement.

A given change in the correlation between the shocks to permanent labor income and equity returns does not necessarily impact all investors' equity holdings equally, it has a larger impact for investors with a higher permanent earnings variance.

Would it be farfetched to use our results as a guideline for portfolio choice in practice? Because a real individual's labor income dynamics will almost certainly differ from the simulated profiles and aggregate variances used here, this question must be answered in the affirmative if results are to be applied literally. If, however, not the final results are applied without reflection, but the underlying determinants, their directions of action, magnitudes and interrelations are internalized and adopted to the individual investor's specific situation, the question must be answered in the negative.

For example, assume you are a highly educated investor. Then, we are not suggesting that you invest exactly the fraction represented by the corresponding line in panel A of Figure 4 in stocks. Instead, think about your labor income dynamics relative to those assumed for the figure: is your labor income more or less variable? Is it correlated with stock returns? What pension can you approximately expect from public provision schemes relative to your earnings? Are you investing on your own or together with your partner? Is it likely that your partner's earnings are correlated with yours? How? Use these and similar questions together with the findings from section 4 to assess how your risky asset exposure should qualitatively differ from that in the figure at each point in time and invest accordingly.

\section{References}

Abrahamsen, Y. and J. Hartwig (2003), „Volkswirtschaftliche Auswirkungen verschiedener Demographieszenarien und Varianten zur langfristigen Finanzierung der Alterssicherung in der Schweiz“, Beiträge zur sozialen Sicherheit, Forschungsbericht Nr. 12/03.

Arellano, M. (2003), Panel Data Econometrics, Oxford et al.

Benzoni, L., P. Collin-Dufresne, and R. Goldstein (2005), "Portfolio Choice over the Life-Cycle in the Presence of Trickle-Down Labor Income", NBER Working Paper 11247. 
Bodie, Z. (2003), "An Analysis of Investment Advice to Retirement Plan Participants", in: O. Mitchell and K. Smetters (eds), The Pension Challenge: Risk Transfers and Retirement Income Security, Oxford et al., pp. 19-32.

Bonjour, D. (1997), Lohndiskriminierung in der Schweiz: Eine ökonometrische Untersuchung, Bern.

Bonjour, D. and M. Gerfin (1995), „Einkommensungleichheit zwischen Frauen und Männern. Eine ökonometrische Analyse der Schweizer Arbeitskräfteerhebung: Kommentar", Swiss Journal of Economics and Statistics, 131, pp. 701-710.

Campbell, J., J. Cocco, F. Gomes, and P. Maenhout (2000), "Investing Retirement Wealth: A Life-cycle Model”, in: J. Campbell and M. Feldstein (eds), Risk Aspects of Investment-Based Social Security Reform, n.l., pp. 439-480.

Campbell, J. and L. Viceira (2002), Strategic Asset Allocation: Portfolio Choice for Long-Term Investors, New York et al.

Carroll, C. (2002), "Lecture Notes on Solution Methods for Microeconomic Dynamic Stochastic Optimization Problems”, Lecture Notes, John Hopkins University.

Carroll, C. and A. Samwick (1997), "The Nature of Precautionary Wealth", Journal of Monetary Economics, 40, pp.41-71.

Cattaneo, A. and R. Winkelmann (2003), "Earnings Differentials Between German and French Speakers in Switzerland", Working Paper No.0309, University of Zurich.

Chiswick, B. (forthcoming), "Jacob Mincer, Experience and the Distribution of Earnings", in: S. Grossbard-Shechtman (ed.), Jacob Mincer, a Pioneer of Modern Labor Economics.

Cocco, J. (2004), "Portfolio Choice in the Presence of Housing", Review of Financial Studies, 18, pp. 535-567.

Cocco, J., F. Gomes, and P. Maenhout (2005), "Consumption and Portfolio Choice over the Life-cycle", Review of Financial Studies, 18, pp.491-533.

Davis, S., F. Kubler, and P. Willen (2004), "Borrowing Costs and the Demand for Equity over the Life Cycle", Working Paper.

Diekmann, A. und H. Engelhardt (1994), „Einkommensungleichheit zwischen Frauen und Männern. Eine ökonometrische Analyse der Schweizer Arbeitskräfteerhebung", Swiss Journal of Economics and Statistics, 131, pp. $57-83$.

Drobetz, W. (2000), „Wie hoch ist die Risikoprämie am Schweizer Aktienmarkt?", Financial Markets and Portfolio Management, 14, pp.364-386.

EDI (2006),“ Der Bundesrat spricht sich gegen eine freie Wahl der Pensionskasse aus", Press release, available at: http://www.news.admin.ch/abo. 
Ernst, C., M. Gerfin, and R. Leu (2000), "Inequality Trends in the Swiss Income Distribution", Swiss Journal of Economics and Statistics, 136, pp. 289-305.

Flueckiger, I. and Z. Ahmad (1996), «Analyse économique des causes des inégalités salariales entre hommes et femmes en Suisse», Rapport scientifique final, PNR 35 «Femmes, Droit et Société», Bern.

Gerber, D. (2002), Freie Pensionskassenwahl in der schweizerischen Altersvorsorge: Ökonomische Analyse eines Systemwechsels zu einer wettbewerblichen Gestaltung der zweiten Säule, Chur and Zurich.

Gerfin, M. (1994), "Income distribution, income inequality and life cycle effects - a nonparametric analysis for Switzerland", Swiss Journal of Economics and Statistics, 130, pp. 509-522.

Gomes, F. and A. Michaelides (2003), "Portfolio Choice with Internal Habit Formation: A Life-cycle Model with Uninsurable Labor Income Risk", Review of Economic Dynamics, 6, pp.729-766.

Gomes, F. and A. Michaelides (2005), "Optimal Life Cycle Asset Allocation: Understanding the Empiric Evidence", Journal of Finance, 60, pp. 869-904.

Gomes, F., A. Michaelides, and V. Polkovnichenko (2004), "Portfolio Choice and Wealth Accumulation with Taxable and Tax-Deferred Accounts", Working Paper.

Gourinchas, P. and J. Parker (2002), "Consumption over the Life Cycle", Econometrica, 70, pp. 47-89.

Gruetter, M. (2005), "Return to Foreign Education. Yet Another But Different Analysis from Swiss Data", Working Paper.

Haliassos, M. and A. Michaelides (2002), "Calibration and Computation of Household Portfolio Models", in: L. Guiso, M. Haliassos, and T. Jappelli (eds), Household Portfolios, Cambridge, pp. 55-101.

Hall, R. and F. Mishrin (1982), "The Sensitivity of Consumption to Transitory Income: Estimates from Panel Data on Households", Econometrica, 50, pp. 461-482.

Hause, J. (1977), "The Covariance Structure of Earnings and the On-thejob-training Hypothesis", Annals of Economic and Social Measurement, 6, pp. 335-365.

Heaton, J. and D. Lucas (2000), "Portfolio Choice in the Presence of Background Risk", The Economic Journal, 110, pp. 1-26.

Henneberger, F. and A. Sousa-Poza (1998), „Lohnunterschiede zwischen Männern und Frauen in der Schweiz - Neueste Schätzungen mit den Mikrodaten der Schweizerischen Arbeitskräfteerhebung von 1995 und 1997“, Discussion Paper No. 52, Research Institute for Labor Economics and Labor Law, St.Gallen. 
Hubbard, R., J. Skinner, and S. Zeldes (1994), "The Importance of Precautionary Motives in Explaining Individual and Aggregate Saving", CarnegieRochester Conference Series on Public Policy, 40, pp. 59-125.

Hubbard, R., J. Skinner, and S. Zeldes (1995), "Precautionary Saving and Social Insurance”, Journal of Political Economy, 103, pp. 360-399.

IDA (2003), „Synthesebericht zum Forschungsprogramm zur längerfristigen Zukunft der Alterssicherung", Beiträge zur sozialen Sicherheit, Forschungsbericht 13/03.

Jagannathan, R. and N. Kocherlakota (1996), "Why should Older People Invest less in Stocks than Younger People", Federal Reserve Bank of Minneapolis Quarterly Review, pp. 11-23.

Klos, A., T. Langer,und M. Weber (2003), „Über kurz oder lang - welche Rolle spielt der Anlagehorizont bei der Beurteilung von Investments?", Zeitschrift für Betriebswirtschaft, 7, pp. 733-765.

KüNG, L. (2005), "The Impact of Immigration on Swiss Wages: A Fixed Effects Two Stage Least Squares Analysis", Working Paper.

Lemieux, T. (forthcoming), "The 'Mincer Equation' Thirty Years after 'Schooling, Experience and Earnings'”, in: S. Grossbard-Shechtman (ed.), Jacob Mincer, a Pioneer of Modern Labor Economics.

Lillard, L. (1977), "Inequality: Earnings vs. Human Wealth", American Economic Review, 67, pp.42-53.

Lillard, L. and Y. Weiss (1979), "Components of Variation in Panel Earnings Data: American Scientists 1960-70”, Econometrica, 47, pp.437-454.

Lillard, L.and R. Willis (1978), "Dynamic Aspects of Earning Mobility, Econometrica, 46, pp. 985-1012.

Luchsinger, C., J. Wild, and R. Lalive (2001), "Do Wages Rise with Job Seniority? The Swiss Case", Centre for Energy Policy and Economics, Working Paper No.7.

Lynch, A. and S. TAN (2004), "Labor Income Dynamics at Business Cycle Frequencies: Implications for Portfolio Choice, NBER Working Paper No. 11010.

MaCurdy, T. (1981), "Multiple Time Series Models Applied to Panel Data", NBER working paper No. 646.

MaCurdy, T. (1982), "The Use of Time Series Processes to Model the Error Structure of Earnings in a Longitudinal Data Analysis", Journal of Econometrics, 18, pp. 83-114.

Merton, R. (1969), "Lifetime Portfolio Selection under Uncertainty: The Continuous-time Case", Review of Economics and Statistics, 51, pp. 247-257.

Merton, R. (1971), "Optimum Consumption and Portfolio Rules in a Continuous-time Model”, Journal of Economic Theory, 3, pp. 373-413. 
Mincer, J. (1974), Schooling, Experience, and Earnings, New York and London. Müller, A., R. Van Nieuw koop, and C. Lieb (2003), „Analyse der Finanzierungsquellen für die AHV: SWISSOLG, ein Overlapping Generations Model für die Schweiz“, Beiträge zur sozialen Sicherheit, Forschungsbericht Nr. 11/03.

Ott, W., M. Baur, A. Schmid, und B. Keller (2005), „Freie Wahl der Pensionskasse: Machbarkeitsstudie“, Beiträge zur sozialen Sicherheit, Forschungsbericht $9 / 05$.

Pittet, D. und M. Рiтtet (2005), „Machbarkeitsstudie zur freien Pensionskassenwahl: Vergleichsstudie über die individualisierte Vorsorge und den Risikotransfer auf die Versicherten", Beiträge zur sozialen Sicherheit, Forschungsbericht 10/05.

PolacheK, S. and W. Siebert (1993), The Economics of Earnings, Cambridge et al.

Polkovnichenko, V. (2007), "Life-cycle Portfolio Choice with Additive Habit Formation Preferences and Uninsurable Labor Income Risk", Review of Financial Studies, 20, pp. 83-124.

Queisser, M. and D. Vittas (2000), "The Swiss Multi-Pillar Pension System: Triumph of Common Sense?”, Working paper.

Roussanov, N. (2004), "Human Capital Investment and Portfolio Choice over the Life-Cycle", Working Paper.

Samuelson, P. (1969), "Lifetime Portfolio Selection by Dynamic Stochastic Programming", Review of Economics and Statistics, 51, pp. 239-246.

Schafer, J. (1997), Analysis of Incomplete Multivariate Data, London.

Schluep, K. (2003), „Finanzierungsbedarf in der AHV (Inkl. EL)“, Beiträge zur sozialen Sicherheit, Forschungsbericht 10/03.

Sheldon, G. (2000), "The Impact of Foreign Labor on Relative Wages and Growth in Switzerland", Working Paper.

Sousa-Poza, A. and F. Henneberger (1998), "Estimating Wage Functions and Wage Discrimination Using Data from the 1995 Swiss Labour Force Survey: A Double Selectivity Approach", International Journal of Manpower, 19, pp. 486-506.

Sousa-Poza, A. and F. Henneberger (2000), "Wage Data Collected by Telephone Interviews: An Empirical Analysis of the Item Nonresponse Problem and Its Implications for the Estimation of Wage Functions", Swiss Journal of Economics and Statistics, 136, pp.79-98.

Sousa-Poza, A. and J. Van Dam (2002), "Policy Approaches to Promote Private and Occupational Old-Age Provision in Switzerland", Bertelsmann Stiftung Vorsorgestudien 7, Working paper. 
Wallmeier, M. and F. Zainhofer (2006), "How to Invest over the Life Cycle: Insights from Theory", Journal für Betriebswirtschaft, 56, pp. 219-244.

Weiss, Y. and L. Lillard (1978), "Experience, Vintage and Time Effects in the Growth of Earnings: American Scientists, 1960-1970", Journal of Political Economy, 86, pp.427-447.

Willen, P. (2003), "Entrepreneurial Investment in a Life-Cycle Portfolio Choice Model”, Working Paper.

YaO, R. and H. Zhang (2005), "Optimal Consumption and Portfolio Choices with risky Housing and Borrowing Constraints", Review of Financial Studies, 18, pp. 197-239.

ZurbrügG, F. (1990), Einkommensentwicklung im Lebenszyklus, Bern.

\section{SUMMARY}

We use panel data from the Swiss Labor Force Survey to estimate age-earnings profiles as well as transitory and permanent income shock variances for investor groups distinguished by gender, education and activity rate. Estimation results are then used to stylize several different Swiss investor types. Finally, we determine optimal life cycle consumption, savings and risky asset share for these investor types using a recent computational life cycle model of portfolio choice suggested by Cocco et al. (2005). We are particularly interested in the allocation differences between the investor types and their normative implications. 